Turkish Online Journal of Qualitative Inquiry (TOJQI)

Cilt 8, Sayı 2, Nisan 2017: 186-215

DOI: $10.17569 /$ tojqi.266133

Araştırma Makalesi

\title{
Matematik Öğretmenlerinin İrrasyonel Sayılara Yönelik Kavram Bilgilerinin İncelenmesi
}

\author{
Gürsel Güler ${ }^{1}$
}

\section{$\ddot{O} \mathbf{z}$}

$\mathrm{Bu}$ araştırmanın amacı matematik öğretmenlerinin irrasyonel sayılara yönelik bilgi düzeylerini incelemektir. Araştırmanın verileri Türkiyenin İç Anadolu Bölgesinde görev yapan sekiz ilköğretim matematik öğretmeni ile yapılan yarı yapılandırılmış görüşmeler yardımıyla toplanmıştır. Öğretmenlerle yapılan mülakatlar ortalama 45 dakika sürmüştür. Yapılan mülakatlar öğretmenlerin izinleri alınarak ses kayıt cihazı ile kayıt edilmiştir. Mülakatların tamamlanmasının ardından ses kayıtları yazıya dökülerek verilerin analizine başlanmıştır. Veriler nitel içerik analizi yöntemi ile analiz edilmiştir. Araştırmacı tarafından görüşme formunun hazırlanması aşamasında ilk olarak literatürde yer alan çalışmalar ve Milli Eğitim Bakanlığı (MEB) tarafından hazırlanan ortaokul ve lise ders kitapları incelenmiştir. Araştırma sonucunda, matematik öğretmenlerinin irrasyonel sayıları tanımlama, tanıma, sayı doğrusu üzerinde irrasyonel sayıların tam yerinin bulunması ve irrasyonel sayılar kümesi üzerinde yaptıkları işlemlere yönelik güçlüklerinin olduğu görülmüştür. Öğretmenler formel matematiksel bilgiler kullanmak yerine daha çok sezgisel yanıtlar vermişlerdir. Matematik öğretmenlerinin irrasyonel sayılara yönelik bilgi düzeylerinin düşük olduğu ve kavram

\footnotetext{
${ }^{1}$ Yard.Doç.Dr., Bozok Üniversitesi, Eğitim Fakültesi, İlköğretim Bölümü, gursel.guler@ bozok.edu.tr Geliş tarihi: 15.11.2016, Kabul tarihi: 19.04.2017
} 
yanılgılarına sahip oldukları görülmüştür. Öğretmenlerin irrasyonel sayılarla ilgili tanımlama, tanıma, sayı doğrusu üzerinde irrasyonel sayıların tam yerinin göstermesi ve irrasyonel sayılar kümesi üzerinde yaptıkları işlemlere yönelik yaşadıkları güçlükler dikkate alınarak daha geniş katılımlı araştırmaların yapılması önerilmiştir.

Anahtar Sözcükler: Matematik ögretmeni, irrasyonel sayl, rasyonel sayı, kavramsal anlama 


\section{Giriş}

İnsanlar günlük yaşamda sayıları sayma, sıralama ve ölçme gibi üç temel amaç için kullanmaktadırlar (Sirotic, 2004). Sayılar ve sayı algılaması, matematik öğretiminin ana temalarından birisidir ve öğretimi okul öncesi dönemden başlayıp ortaöğretim sonlarına kadar yoğun bir şekilde devam eden zorlu bir süreci kapsar (Güler, Kar ve Işı1, 2012). Öğrenciler açısından matematik eğitiminin başarıyla yürütülebilmesi için özellikle ilköğretim ve ortaöğretim matematik öğretim programlarının temel öğrenme alanlarından sayılar sisteminin (Baki, 2008) üzerinde titizlikle durulmasını gerektirmektedir. Ancak sayı kavramının nasıl oluştuğunu kavramak o kadar da kolay değildir (Sirotic, 2004). Çünkü ileri seviye matematiksel kavramların anlaşılması sürecinde öğrencilerin temel sayma becerisinden daha fazlasına ihtiyaçları olduğu açıktır. Özellikle ileri seviye matematik kavramları düşünüldüğünde sayılar ve sayı kümelerinin önemi daha fazla hissedilmektedir. $\mathrm{Bu}$ süreçte öğrencilerin temel sayma becerilerinden daha ileri düzey sayı bilgisi oluşturmaları, basamak kavramını ve sayı örüntülerini anlamaları, sayılarla işlem yapma ve sayılar arasındaki ilişkileri oluşturabilme becerilerinin geliştirilmesi hedeflenir. Ancak sayıların algılanması, sayıların çokluk değeri ve basamak kavramının öğretiminden daha fazlasını gerektirir (Güler, Kar ve Işı1k, 2012).

National Council of Teachers of Mathematics [NCTM] Okul Matematiği için İlkeler ve Standartlar (2000) raporunda; lise öğrencilerinin bir sayı sistemini tam olarak anlamaları için diğer sayı sistemleriyle olan ilişkisinin nasıl olduğu ve bir sayı sistemindeki özelliklere başka bir sayı sisteminin de sahip olup olmadığını anlamakla mümkün olabileceğini belirtmektedir. İleri seviye matematiksel kavramların anlaşılmasında reel sayılara yönelik yeterli bilgiye sahip olmak oldukça önemlidir (Güven, Çekmez ve Karataş, 2011). Ancak sayı kümeleri arasındaki sıkı hiyerarşi ve özellikle de irrasyonel sayılar kümesinin kendine özgü soyut yapısı reel sayıların öğretiminde öğrencilerin güçlük yaşamalarına sebep olmaktadır. Bu durum irrasyonel sayılarla ilgili literatürde yer alan çalışmaların sonuçlarında açıça görülmektedir (Fischbein, Jehiam ve Cohen, 1995; Güven, Çekmez ve Karataş, 2011; Kara ve Delice, 2012; Sirotic, 2004; Sirotic ve Zazkis, 2007). Reel sayılara yönelik bilgiler öğrencilerin rasyonel ve irrasyonel sayıları anlamaları ile doğrudan ilişkili olduğu için irrasyonel sayıların anlaşılması rasyonel sayıların anlaşılması açısından da önemlidir (Güven, Çekmez ve Karataş, 2011). Ancak okul matematiğinde irrasyonel sayıların öğretimi üzerinde çok fazla durulmamaktadır (Fischbein, Jehiam ve Cohen, 1995). Bununla birlikte irrasyonel sayıların anlaşılmasına yönelik çalışmalarında sınırlı sayıda olduğu söylenebilir (Sirotic, 2004; Sirotic ve Zaskis, 2007). Ayrıca literatürde yer alan çalışmalar da irrasyonel sayıların anlaşılmasında öğrencilerin güçlük yaşadıkları ve kavram yanılgılarına sahip oldukları tespit edilmiştir (Adigüzel, 2013; Arcavi, Bruckheimer, Ben-Zvi, 1987; Ercire, 2014; Fischbein, Jehiam ve Cohen, 1995; Güven, Çekmez ve Karataş, 2011; Kara ve Delice, 2012; Peled ve Hershkovitz, 1999; Sirotic, 2004; Sirotic ve Zazkis, 2007; Temel ve Eroğlu, 2014; Zazkis, 2005). 


\section{İrrasyonel Sayıların Anlaşııması Üzerine Yapılan Çalışmalar}

İrasyonel sayıların anlaşılması üzerine yapılan çalışmalar incelendiğinde; verilen bir kümedeki elemanların hangilerinin rasyonel hangilerinin irrasyonel olduğunun belirlenmesi (Adıgüzel, 2013; Ercire, 2014; Fischbein, Jehiam ve Cohen, 1995; Güven, Çekmez ve Karataş, 2011; Kara ve Delice, 2012; Peled ve Hershkovitz, 1999; Sirotic, 2004; Temel ve Eroğlu, 2014), rasyonel ve irrasyonel sayıların tanımlarının yapılması (Adıgüzel, 2013; Ercire, 2014; Fischbein, Jehiam ve Cohen, 1995; Güven, Çekmez ve Karataş, 2011; Kara ve Delice, 2012; Sirotic, 2004), irrasyonel sayıların farklı gösterimlerinin yapılması (Peled ve Hershkovitz, 1999; Sirotic, 2004), irrasyonel sayıların sayı doğrusu üzerinde gösterilmesi (Peled ve Hershkovitz, 1999; Sirotic, 2004; Sirotic ve Zazkis, 2007), irrasyonel sayılar kümesi üzerinde yapılan işlemler (Adıgüzel, 2013; Ercire, 2014; Güven, Çekmez ve Karataş, 2011) ve irrasyonel sayılara yönelik yaşanan kavram yanılgılarının (Arcavi, Bruckheimer, Ben-Zvi, 1987; Fischbein, Jehiam ve Cohen, 1995) farklı örneklem grupları üzerinde araştırıldığ́ görülmektedir. Bununla birlikte araştırmaların büyük bir bölümünde irrasyonel sayılarla ilgili sıralanan durumların bir veya birkaçı birlikte ele alınmıştır.

İrasyonel sayıların anlaşılması ile ilgili bir sayı kümesindeki elemanlardan hangilerinin irrasyonel oldukların belirlenmesine yönelik yapılan bir çalışmada; Fischbein, Jehiam ve Cohen (1995) lise öğrencileri ve matematik öğretmeni adaylarının verilen bir sayı kümesi içerisindeki sayıların rasyonel, irrasyonel ya da reel sayı olduklarını ayırt etmekte güçlükler yaşadıklarını tespit etmişlerdir. Özellikle güçlük yaşanan sayıların $\pi,-\frac{22}{7}, 0,12122 \ldots$ şeklindeki sayılar olduğu görülmüştür. Bu sayıların rasyonel ya da irrasyonel olduğunun ayırt edilmesinde yaşanan güçlüklerin ise irrasyonel sayıların sınırlı örneklerle $(\sqrt{2}, \sqrt{3}, \pi)$ tanıtılmasından kaynaklandığı vurgulanmıştır. Ayrıca çalışmada hem lise öğrencilerinin hem de öğretmen adaylarının rasyonel, irrasyonel ve reel sayı kavramlarını doğru bir şekilde tanımlayamadıkları görülmüştür. Ancak Peled ve Hershkovitz (1999) çalışmalarında Fischbein, Jehiam ve Cohen (1995)'in aksine öğretmen adaylarının irrasyonel sayıların tanımını bildikleri sonucuna ulaşmıştır. Bununla birlikte katılımcıların tanımını ve özelliklerini bildikleri irrasyonel sayıların farklı gösterimlerini yapmakta güçlüklerinin olduğu görülmüştür. Ayrıca Ercire, Narlı ve Aksoy (2016) sekizinci ve dokuzuncu sınıf öğrencilerinin irrasyonel sayıların tamamının gerçek sayı olamayabileceği düşüncesi ile bir sayının hem rasyonel hem de irrasyonel olabileceği düşüncesine sahip olduklarını belirtmişlerdir.

İrasyonel sayıların farklı gösterimleri ve sayı doğrusu üzerindeki yerleriyle ilgili yapılan bir çalışmada Sirotic ve Zazkis (2007), $\sqrt{5}$ sayısının sayı doğrusu üzerindeki tam yerini bulabilir miyiz? sorusu ile ortaöğretim matematik öğretmeni adaylarının kendi irrasyonel sayı gösterimlerini ve kavrayışlarını araştırmışlardır. Araştırma sonucunda öğretmen adaylarının 
$\sqrt{5}$ sayısının sayı doğrusu üzerindeki yerini göstermek için beş farklı kategoride yer alan yanıtlarının olduğu belirlenmiştir. Ancak bu gösterim şekillerinden sadece Pisagor Teoremini kullanan adayların $\sqrt{5}$ sayısının sayı doğrusundaki tam yerini belirledikleri görülmüştür. Dolayısıyla araştırma sonucunda öğretmen adaylarının irrasyonel sayıların sayı doğrusu üzerindeki tam yerlerini tespit etmekte güçlükler yaşadıkları, irrasyonel sayılar ve ondalıklı gösterimlerinin kafalarını karıştırdığı görülmüştür. Ayrıca elde edilen sonuçlar öğretmen adaylarının irrasyonel sayılarla ilgili sezgileri ile formal ve algoritmik bilgileri arasında tutarsızlıkların olduğuna işaret etmiştir. Benzer şekilde Peled ve Hershkovitz (1999) öğretmen adaylarıyla yaptıkları araştırmada $\sqrt{4}, \frac{1}{100}, 0.12,0.25, \pi, \sqrt{5}, \frac{1}{9}, 0.3333 \ldots$ sayılarının sayı doğrusu üzerinde gösterilip gösterilemeyeceğini araştırmışlardır. Araştırma sonucunda öğretmen adayları özellikle $\pi, \sqrt{5}, 0.3333 \ldots$ sayılarını sayı doğrusu üzerinde göstermekte güçlükler yaşamışlardır. Özellikle öğretmen adaylarının, irrasyonel sayıların ve devirli ondalık sayıların virgülden sonra sonsuz basamağa sahip olmalarından kaynaklan güçlükleri olduğu tespit edilmiştir. Ayrıca öğretmen adaylarının sadece irrasyonel sayı algılarında değil aynı zamanda ondalıklı sayılar ile rasyonel sayılar arasındaki dönüşümleri yapmakta da güçlük yaşadıkları görülmüştür. Adayların $0.3333 \ldots=\frac{1}{3}$ şeklindeki dönüşümleri yapamadıkları için bu sayıların sayı doğrusu üzerindeki yerlerini tespit etmekte güçlük yaşadıkları gözlenmiştir.

Matematik öğretmeni adaylarının irrasyonel sayılarla ilgili anlayışlarını üç boyutta inceleyen Güven, Çekmez ve Karataş (2011) tarafindan gerçekleştirilen çalışmada; rasyonel ve irrasyonel sayıların tanımları, rasyonel ve irrasyonel sayıların sayı doğrusundaki yerleri ve rasyonel ve irrasyonel sayılarla yapılan işlemler üzerine odaklanılmıştır. İrrasyonel sayılarla ilgili yapılmış olan çalışmalar bu üç boyut üzerine odaklandığı için araştırmada bu şekilde bütüncül bir yaklaşım seçilmiştir. Araştırma birinci ve dördüncü sınıfta öğrenim gören öğretmen adaylarından oluşan 80 katılımcı ile yürütülmüştür. Çalışma sonucunda katılımcıların büyük bir bölümünün rasyonel ve irrasyonel sayıları doğru bir şekilde tanımlayamadıkları ve irrasyonel sayılarla kompleks sayıların karıştırıldığı görülmüştür. Bununla beraber özellikle birinci sınıf öğrencilerinde $\pi$ sayısının rasyonel sayı olduğu şeklinde bir yanılgının olduğu ancak dördüncü sınıf öğrencilerinin $\pi$ sayısını irrasyonel olarak gördükleri belirlenmiştir. Ayrıca irrasyonel sayılarla ilgili öğretmen adaylarında "irrasyonel sayılar=köklü sayılar" şeklinde bir düşüncenin hakim olduğu ve özellikle virgülden sonrası sonsuz olan ondalık sayıların periyodik olup olmamasına bakılmaksızın irrasyonel sayı olarak düşünüldüğü tespit edilmiştir. Öğretmen adaylarının sayı doğrusu üzerinde sayıları yerleştirme konusunda sezgilerinden yararlanarak genelde doğru yanıtlar verdikleri gözlenmiştir. İrrasyonel ve rasyonel sayılarla yapılan işlemlerle ilgili olarak ise iki irrasyonel sayının toplamı ve çarpımı sonuçlarının her zaman irrasyonel olacağını şeklinde yanlış düşünceye sahip adayların çoğunlukta olduğu görülmüştür. Bununla birlikte Ercire (2014) yüksek lisans tez çalışmasında ortaokul sekizinci ve lise dokuzuncu sınıf öğrencilerinin irrasyonel sayılarla toplama ve çarpma işlemleri sonuçlarının irrasyonel sayı olması gerektiği yönünde yanlış öğrenmelere sahip olduklarını belirtmiştir. Ayrıca öğrencilerin özellikle iki irrasyonel sayının toplamında kavram yanılgılarının arttığı ancak iki 
irrasyonel sayının çarpımında köklü ifadelerin çarpımından yola çıkıldığı durumlarda işlem sonucunun rasyonel olabileceği yönündeki yanıtların arttı̆̆ı vurgulanmaktadır. Benzer şekilde Adıgüzel (2013) yüksek lisans tez çalışmasında ortaokul sekizinci sınıf öğrencileri ve matematik öğretmen adaylarının irrasyonel sayılarla ilgili bilgileri ve kavram yanılgılarını araştırmıştır. Çalışmada öğretmen adaylarının çoğunluğunun irrasyonel sayıların toplama işlemine kapalı olduğu yanılgısına sahip olduklarını vurgulanmıştır. Çarpma işleminde ise öğretmen adaylarının çoğunluğunun (aynı köklü ifadelerin çarpımını düşünmeleri sonucunda) kapalılık özelliğinin sağlanmadığının farkında oldukları görülmüştür.

Öğretmen ve öğretmen adaylarının irrasyonel sayılarla ilgili inanışlarının ve kavram yanılgılarının incelendiği çalışmada ulaşılan en önemli sonuç irrasyonel sayılarla ondalıklı sayıların birlikte düşünülmesi olarak ifade edilmiştir (Arcavi, Bruckheimer ve Ben-Zvi, 1987). Ayrıca öğretmenlerin büyük çoğunluğu tarafından tarihsel gelişim olarak irrasyonel sayıların ne zaman ortaya çıktığı bilinmesine rağmen nasıl oluşturulduğunun bilinmediği görülmüş̧tür. Bununla beraber katılımcıların ondalık sayıların irrasyonel sayılardan daha önce bulunduğu şeklinde bir yanılgıya sahip oldukları tespit edilmiştir. $\mathrm{Bu}$ durumun irrasyonel sayıların geometrik yorumunun yapılamamasından ve sadece ondalıklı sayılarla ilişkilendirilmesinden kaynaklandığı belirtilmiştir. Dolayısıyla katılımcıların irrasyonel sayıların kıyaslanamayan (commensurable) ve sayılamayan (incommensurable) uzunluk olarak ortaya çıktığını bilmedikleri görülmüştür.

\section{Türkiye’de Öğretim Programlarında İrrasyonel Sayıların Yeri}

Türkiye de Milli Eğitim Bakanlığı [MEB] tarafından 2013 yılında güncellenen öğretim programlarına göre irrasyonel sayılar konusu ilk olarak 8. sınıf düzeyinde "Sayılar ve İşlemler" öğrenme alanı içerisinde yer almaktadır. Öğrencilerin 8. sınıf düzeyinde gerçek sayıları tanımaları ve rasyonel sayılar ile irrasyonel sayılar arasında ilişkiler kurabilmeleri ele alınmaktadır (MEB, 2013a). Öğretim programı incelendiğinde bu sınıf düzeyinde "Kareköklü İfadeler" konusu içerisinde irrasyonel sayılarla ilgili "Gerçek sayıları tanır, rasyonel ve irrasyonel sayılarla ilişkilendirir." şeklinde bir kazanım olduğu görülmektedir. Bununla birlikte 8. sınıf düzeyinde irrasyonel sayıların öğretiminde, "Tam kare olmayan sayıların kareköklerinin rasyonel sayı olarak belirtilemediğine (iki tam sayının oranı şeklinde yazılamadığına) dikkat çekilir. $\pi$ sayısı bir irrasyonel sayı olarak tanıtılır." şeklinde bir alt kazanım bulunmaktadır. Ayrıca MEB tarafindan hazırlanan ve 8. sinıf düzeyinde okutulan ders kitabı (MEB, 2015a) incelendiğinde ise "Kareköklü İfadeler" konusu içerinde irrasyonel sayılarla ilgili oldukça geniş bir bölüm bulunduğu görülmektedir. Bu bölümde irrasyonel sayılarla ilgili; irrasyonel sayıları tanıma, geometri ile olan tarihsel ilişkisi, ilk kez ne zaman ortaya çıktığı, yaklaşık değerlerini tahmin etme, sayı doğrusu üzerinde gösterme, farklı gösterimleri ve diğer sayı kümeleri ile olan ilişkisi üzerinde durulmaktadır. Aşağıda irrasyonel sayılarla ilgili 8. Sınıf Matematik Ders kitabında yer alan bazı etkinlik, örnek ve problemlere yer verilmiştir. 


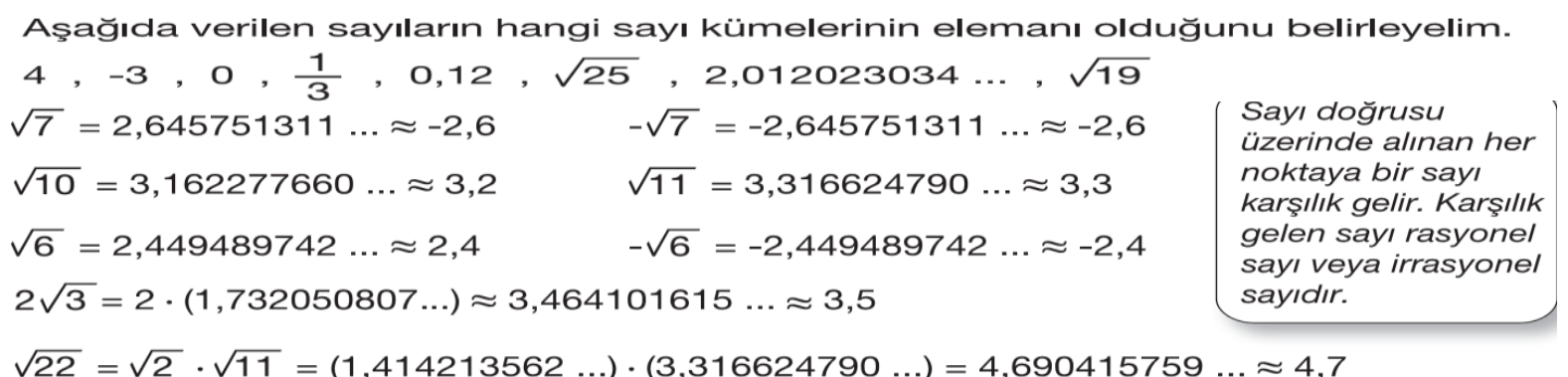

$\mathrm{Bu}$ irrasyonel sayıların yaklaşık değerlerini sayı doğrusunda aşağıdaki gibi gösterebiliriz.

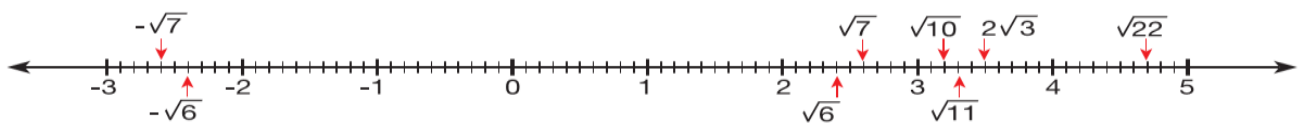

Şekil 1. İrrasyonel sayıların yaklaşık değerleri ve sayı doğrusu üzerindeki yerlerine yönelik problem örneği (MEB, 2015a)

Öğretim programlarına göre irrasyonel sayılar ikinci olarak 9. sınıf düzeyinde karşımıza çıkmaktadır. Bu sınıf düzeyinde "Sayılar ve Cebir" öğrenme alanında "Denklem ve Eşitsizlikler" ünitesi içerisinde "Gerçek Sayılar" konusunda "İrrasyonel sayılar ve gerçek sayılar kümesini açıklar." şeklinde bir kazanım yer almaktadır (MEB, 2013b). Bununla birlikte 9. sınıf düzeyinde irrasyonel sayıların öğretiminde " $\sqrt{2}$ sayısının bir rasyonel sayı olmadığı ispatlanır; sayı doğrusundaki yeri belirlenir." ve "Gerçek sayılar kümesinde toplama ve çarpma işlemlerinin özellikleri incelenir." şeklinde iki alt kazanım bulunmaktadır. Ayrıca 9. Sınıf Matematik Ders Kitabı (MEB, 2015b) incelendiğinde irrasyonel sayıların tarihi, nasıl ortaya çıktığı, tanımı, $\sqrt{2}$ nin irrasyonel olduğunun ispatı, sayı doğrusu üzerindeki yerleri, diğer sayı kümeleri ile olan ilişkisi ve irrasyonel sayılar kümesi üzerinde yapılan işlemlerle ilgili bilgiler verildiği görülmektedir. Bununla birlikte 8 . Sınıf düzeyinde irrasyonel sayılar, $a$ ve $b$ iki tam sayı ve $b \neq 0$ olmak üzere $\frac{a}{b}$ şeklinde yazılamayan sayılardır şeklinde tanımlanırken 9. Sınıf düzeyinde irrasyonel sayıların tanımının $a$ ve $b$ iki tam sayı ve $b \neq 0$ olmak üzere $\frac{a}{b}$ şeklinde yazılamayan ve ondalık açılımı sınırsız ve tekrarsız olan sayılardır şeklinde daha detaylı yapıldığı görülmektedir. Ayrıca 9. sınıf düzeyinde $\pi$ sayısının neden $\frac{22}{7}, \frac{25}{8}, \frac{355}{113}$ sayılarına eşit olmadıklarıyla ilgili de bilgiler verilmiştir. Bununla birlikte irrasyonel sayılar kümesi üzerinde yapılan işlemlerin kapalı olup olmadıklarına yönelik etkinliklere de yer verildiği görülmüştür. Aşağıda irrasyonel sayılarla ilgili 9. Sınıf Matematik Ders kitabında yer alan bazı etkinliklere yer verilmiştir. 

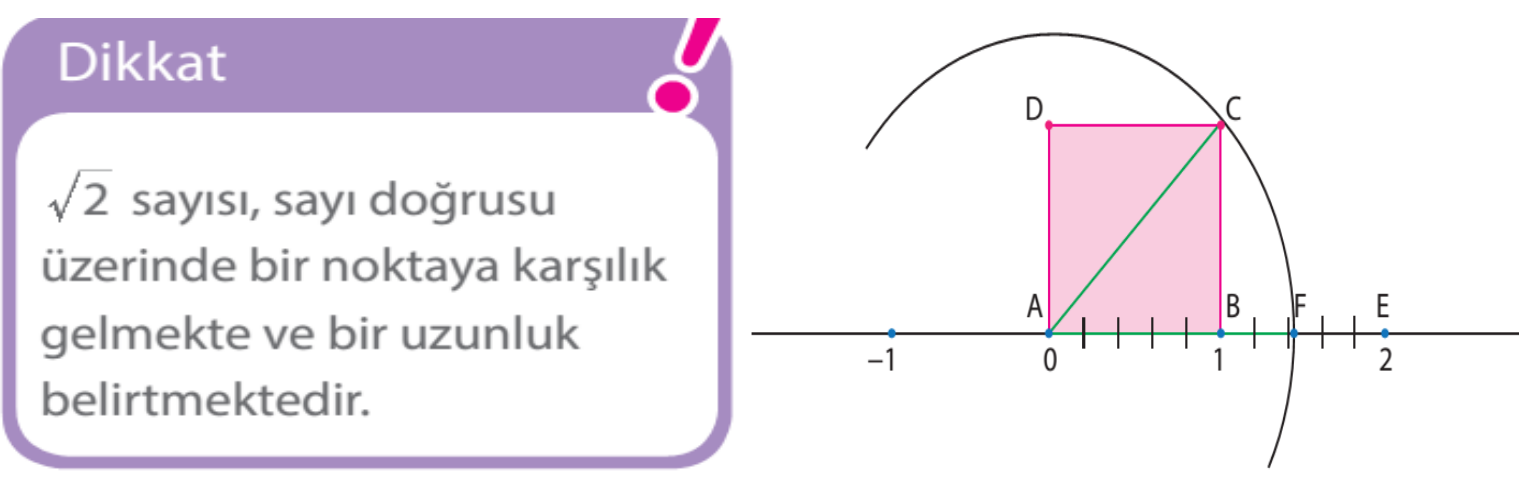

Şekil 2. İrrasyonel sayıların sayı doğrusu üzerindeki tam yerinin bulunmasına yönelik bilgiler (MEB, 2015b)

İlköğretim ve ortaöğretim matematik öğretmeni adayları lisans öğrenimlerinde birçok derste irrasyonel sayılarla karşılaşmaktadırlar. İlköğretim matematik öğretmenliği programının birinci yılında öğrenciler "Genel Matematik" dersi kapsamında doğal sayıları Peano Aksiyomuna göre tanımlamakta ve sonra diğer sayı kümelerinin tamamını oluşturmaktadırlar (Güven, Çekmez ve Karataş, 2011). Benzer şekilde ortaöğretim matematik öğretmenliği programında da irrasyonel sayılar "Soyut Matematik" ve “Analiz I" dersleri kapsamında detaylı olarak ele alınmaktadır.

\section{Çalışmanın Amacı ve Araştırma Problemleri}

İrasyonel sayıların anlaşılması üzerine yapılan araştırmalarda farklı örneklem gruplarındaki katılımcıların öğrenme güçlüklerinin ve kavram yanılgılarının olduğu görülmektedir. Öğrencilerin irrasyonel sayılarla ilgili kavram gelişimleri hiç şüphesiz onlara eğitim veren matematik öğretmenleriyle doğrudan ilişkilidir. Bu yüzden irrasyonel sayılara yönelik matematik öğretmenlerinin kavram bilgilerinin ve varsa eksiklikliklerinin ortaya çıkarılması önem arz etmektedir. Ayrıca irrasyonel sayılara yönelik yapılmış olan çalışmalarda matematik öğretmenleri ile yürütülen araştırmaların da sınırlı olduğu görülmektedir. $\mathrm{Bu}$ yüzden araştırmada matematik öğretmenlerinin irrasyonel sayılara yönelik kavram bilgilerinin araştırılması amaçlanmıştır. Bu şekilde araştırmanın matematik öğretmenlerinin varsa öğrenme güçlükleri ve kavram yanılgıları tespit edilerek giderilmesine yönelik önlemlerin alınmasına katkı sağlayacağı düşünülmektedir. Dolayısıyla bu amaç doğrultusunda aşağıdaki araştıma problemlerine yanıt aranmıştır.

- Matematik öğretmenlerinin irrasyonel ve rasyonel sayıları tanımlama ve tanıma durumları nelerdir?

- Matematik öğretmenlerinin irrasyonel sayıların sayı doğrusundaki tam yerini gösterebilmelerine yönelik bilgi durumları ve kullandıkları stratejiler nelerdir?

- Matematik öğretmenlerinin iki irrasyonel ve rasyonel sayı arasına başka sayılar yazarken kullandıkları stratejiler nelerdir?

- Matematik öğretmenlerinin irrasyonel ve rasyonel sayılarla yapılan toplama ve çarpma işlemlerinin kapalılık özelliğine yönelik bilgilerinin uygulamaya yansımaları nelerdir? 


\section{Yöntem}

\section{Katılımcılar}

Araştırma 2015-2016 eğitim öğretim yılı güz döneminde İç Anadolu bölgesinde yer alan bir ildeki ilköğretim okullarında görev yapan 8 matematik öğretmeni ile yürütülmüştür. Katılımcılardan 3 kişi kadın ve 5 kişi ise erkek öğretmenlerdir. Araştırmada öğretmenlerin seçimi için il merkezinde bulunan bütün ilköğretim okulları listelenmiş ve bu okullarda görev yapan matematik öğretmenleri araştırmanın amacı hakkında bilgilendirilmiştir. Yapılan bilgilendirme aşamasının ardından il merkezinde görev yapmakta olan 124 matematik öğretmeni içerisinden 8 matematik öğretmeni araştırmaya katılmaya gönüllü olmuşlardır. Katılımcıların seçiminde maksimum çeşitlilik örnekleme yöntemi kullanılmıştır. Çünkü bu örnekleme yönteminde örneklemin problemle ilgili olarak kendi içinde benzeşik farkl1 durumlardan oluşturulması amaçlanmaktadır (Büyüköztürk vd., 2011). Buna göre öğretmenlerin kıdemleri göz önüne alınarak 1-5 yıl arası 2, 5-10 yıl arası 2, 10-15 yıl arası 2 ve 15 yıl ve üzeri kıdemi olan 2 öğretmenin çalışmaya dahil edilmesi sağlanmıştır. Araştırmaya katılan her bir öğretmenin isimlerinin gizli kalması için araştırmacı tarafından Ö1, Ö2,..,Ö8 şeklinde kod isimler verilmiştir.

\section{Veri Toplama Aracı ve Analizi}

Araştırmada veri toplama aracı olarak araştırmacı tarafından oluşturulan yarı yapılandırılmış görüşme formu kullanılmıştır. Araştırmacı tarafından görüşme formunun hazırlanması aşamasında ilk olarak literatürde yer alan çalışmalar (Fischbein, Jehiam ve Cohen, 1995; Güven, Çekmez ve Karataş, 2011; Peled ve Hershkovitz, 1999; Sirotic, 2004; Sirotic ve Zazkis, 2007) ve MEB tarafından hazırlanan ortaokul ve lise ders kitapları incelenmiştir. İrasyonel sayıların anlaşılmasına yönelik çalışmalarda genel olarak Güven, Çekmez ve Karataş (2011) tarafindan da belirtildiği gibi üç boyut üzerinde durulduğu görülmüştür. Benzer şekilde araştırmacı; "Rasyonel ve irrasyonel sayıların tanımlanması ve verilen bir sayı kümesindeki sayıların rasyonel ya da irrasyonel olarak sınıflandırılması", "İrrasyonel sayıların sayı doğrusundaki yerinin bulunması, iki rasyonel ve irrasyonel sayının arasına başka sayıların yazılması" ve "Rasyonel ve irrasyonel sayılarla yapılan işlemler" olmak üzere üç durum üzerine odaklanmıştır. Hazırlanan mülakat formu matematik eğitimi alanındaki 3 uzmanın görüşü alınarak tekrar düzenlenmiş ve 5 matematik öğretmeni adayı ile mülakatlar yapılmıştır. Mülakat formunda yer alan kategoriler ve soruların son şekli Tablo 1 de sunulmuştur. 
Tablo 1

Mülakat Formunda Yer Alan Sorular ve Kategorileri

\begin{tabular}{ll}
\hline \multicolumn{1}{c}{ Kategori } & \multicolumn{1}{c}{ Sorular } \\
\hline Rasyonel ve irrasyonel & Rasyonel ve irrasyonel sayıların tanı1 \\
sayıların tanımlanması ve & $A=\left\{-5, \frac{22}{7}, \frac{1}{3}, 3 \sqrt{3}, 1.92713 \ldots, 3+\right.$ \\
verilen bir sayı kümesindeki & $\left.\sqrt{2}, 1.2555 \ldots, \sqrt[3]{3}, \sqrt{36}, \frac{3}{\pi}, 3.14\right\}$ \\
sayıların rasyonel ya da & A
\end{tabular}

irrasyonel olarak

sinıflandırılması

İrasyonel sayıların sayı

doğrusundaki yerinin

bulunmas1, iki rasyonel ve

irrasyonel sayının arasına

başka sayıların yazılması

Rasyonel ve irrasyonel sayılarla yapılan işlemler
A kümesindeki sayıların hangilerinin rasyonel hangilerinin irrasyonel sayı olduğunu sebepleri ile birlikte gösteriniz.

$\sqrt{2}$ sayısının sayı doğrusu üzerindeki tam yerini gösteriniz. İki irrasyonel sayı arasında her zaman başka bir irrasyonel sayı bulabilir miyiz? Neden?

- $\sqrt{2}$ ile $\sqrt{3}$ arasında başka bir irrasyonel sayı yazabilir misiniz?

İki irrasyonel sayı arasında her zaman bir rasyonel sayı bulabilir miyiz? Neden?

- $\sqrt{2}$ ile $\sqrt{3}$ arasinda bir rasyonel sayı yazabilir misiniz?

İki rasyonel sayı arasında her zaman başka bir rasyonel sayı bulabilir miyiz? Neden?

$\bullet \frac{1}{3}$ ile $\frac{1}{2}$ arasında başka bir rasyonel sayı yazabilir misiniz? İki rasyonel sayı arasında her zaman bir irrasyonel sayı bulabilir miyiz? Neden?

$\bullet \frac{1}{3}$ ile $\frac{1}{2}$ arasında bir irrasyonel sayı yazabilir misiniz?

İki irrasyonel sayının toplamı her zaman irrasyonel bir sayı midır? Neden?

- Cevap hayır ise; toplama işleminin irrasyonel sayılar kümesi üzerinde kapalı olmadığını gördük. Dolayısıyla toplama işlemi irrasyonel sayılar kümesi üzerinde tanımlı değildir. Peki, o zaman bu işlemi irrasyonel sayılar kümesi üzerinde nasıl yapabiliriz? Açıklayınız.

İki irrasyonel sayının çarpımı her zaman bir irrasyonel sayı midir? Neden?

- Cevap hayır ise; çarpma işleminin irrasyonel sayılar kümesi üzerinde kapalı olmadığını gördük. Dolayısıyla çarpma işlemi irrasyonel sayılar kümesi üzerinde tanımlı değildir. Peki, o zaman bu işlemi irrasyonel sayılar kümesi üzerinde nasıl yapabiliriz? Açıklayınız.

İki rasyonel sayının toplamı her zaman bir rasyonel sayı midir? Neden?

İki rasyonel sayının çarpımı her zaman bir rasyonel sayı midir? Neden?

Araştırmanın veri toplama süreci yaklaşık bir ay sürmüştür. Araştırmaya katılan matematik öğretmenleri ile kendilerinin belirledikleri günlerde kendi okullarında mülakatlar 
gerçekleştirilmiştir. Mülakatlar araştırmacı ile öğretmenlerin birebir görüşebilecekleri sessiz bir ortamda yapılmıştır. Mülakat sırasında öğretmenlerden kendi çözümlerini yapmaları ve sesli düşünmeleri istenmiştir. Öğretmenlerle yapılan mülakatlar ortalama 45 dakika sürmüştür. Yapılan mülakatlar öğretmenlerin izinleri alınarak ses kayıt cihazı ile kayıt edilmiştir. Mülakatların tamamlanmasının ardından ses kayıtları yazıya dökülerek verilerin analizine başlanmıştır. Veriler nitel içerik analizi yöntemi ile analiz edilmiştir. Araştırmada elde edilen verilerin analizi sürecinde öğretmenlerin yanıtları ilk olarak araştırmacı tarafından kodlanmıştır. Araştırmacı tarafından kodlanan veriler matematik eğitimi alanında uzman iki matematik eğitimcisi tarafından kontrol edilmiştir. Verilerin kodlanmasında literatürdeki çalışmalardan (Fischbein, Jehiam ve Cohen, 1995; Güven, Çekmez ve Karataş, 2011; Peled ve Hershkovitz, 1999; Sirotic, 2004; Sirotic ve Zazkis, 2007) yararlanılmıştır. Daha sonra elde edilen kodlar yardımıyla öğretmenlerin kullandıkları stratejiler kategorize edilmiş ve tablolar halinde sunulmuştur. Ayrıca araştırmacı tarafından öğretmenlerin kullandıkları stratejilere ait kategoriler mülakatlardan alınan doğrudan alıntılarla betimsel olarak desteklenmiştir.

\section{Bulgular ve Yorum}

\section{Rasyonel ve İrrasyonel Sayıları Tanımlama ve Tanıma}

Matematik öğretmenlerinin rasyonel ve irrasyonel sayılara yönelik yaptıkları tanımların sınıflandırılması Tablo 2 de sunulmuştur. Tablo incelendiğinde öğretmenlerin hem rasyonel sayıları hem de irrasyonel sayıları tanımlarken kullandıkları matematiksel dilin zayıf olduğu görülmektedir. Rasyonel sayıların Formel (Matematiksel) tanımını yapabilen sadece 2 (Ö5, Ö8) öğretmen, irrasyonel sayıların ise matematiksel tanımını yapabilen hiçbir öğretmenin olmadığı görülmektedir. Rasyonel sayıların tanımı yapılırken öğretmenlerin genelde eksik tanımlarının pay ve paydadaki sayıların aralarında asal olması gerektiğine vurgu yapmamalarından kaynaklandığı gözlenmiştir. Bununla birlikte öğretmenlerin rasyonel sayılarla ilgili tanımlarında pay ve paydadaki sayıların hangi sayı kümesine ait olması gerektiğini belirtmedikleri de görülmüştür. Özellikle irrasyonel sayıların matematiksel tanımının oluşturulamaması rasyonel sayıların tanımının eksik yapılması ile ilişsilidir. Çünkü öğretmenler genelde irrasyonel sayılar için "Rasyonel olmayan sayılardır” şeklinde yanıtlar vermişlerdir. $\mathrm{Bu}$ durum irrasyonel sayıların ondalık gösterimlerini tam olarak açıklamadığı için eksik olarak değerlendirilmiştir. Ayrıca rasyonel sayıların tanımını formel (Matematiksel) olarak yapan öğretmenlerin de irrasyonel sayıları tanımlarken eksik ve irrasyonel sayıları tam olarak açıklamayan tanımlar yaptıkları gözlenmiştir. Öğretmenlerin irrasyonel sayılarla ilgili eksik tanımlarında bir diğer nokta ise özellikle ondalıklı gösterimlerden kaynaklanmaktadır. Öğretmenler tanımlarında ondalıklı bir sayının irrasyonel olmasını virgülden sonrası sonsuza kadar devam eden sayılardır şeklinde ifade etmişlerdir. $\mathrm{Bu}$ şekilde yapılan bir tanıma göre $0, \overline{3}$ şeklindeki devirli ondalık sayıların da irrasyonel olabileceği yanılgısı ortaya çıkabilir. Aşağıda Ö1, Ö5 ve Ö6 kodlu öğretmenlerin rasyonel ve irrasyonel sayılara yönelik yaptıkları tanımlardan örnekler sunulmuştur. 
Tablo 2

Öğretmenlerin Rasyonel ve İrasyonel Sayılara Yönelik Kullandıkları Tanımlar

\begin{tabular}{lcc}
\hline Tanım & Rasyonel Say1 & İrasyonel Say1 \\
\hline Eksik & Ö1, Ö2, Ö3, Ö4, Ö6, Ö7 & Ö1, Ö2, Ö3, Ö4, Ö5, Ö6, Ö7, Ö8 \\
Formel (Matematiksel) & Ö5, Ö8 & - \\
\hline
\end{tabular}

Ö1: Rasyonel sayılar $\frac{a}{b}$ şeklinde yazılabilen $a, b \in \mathbb{Z}$ ve $b \neq 0$ şeklinde yazılabilen sayılardır. Irrasyonel sayılar ise bu şekilde yazllamayan ya da virgülden sonraki kısmı sonsuza kadar devam eden sayılardır şeklinde tanımlayabiliriz.

Ö5: Rasyonel sayllar: $\left\{\frac{a}{b} ; a, b \in \mathbb{Z}\right.$ ve $\left.b \neq 0\right\}$ şeklinde yazllabilen ve $(a, b)=1$ şartını sağlayan sayılardır. Irrasyonel sayılar ise bu şekilde yazılamayan sayılardır şeklinde tanımlayabiliriz.

Ö6: Irrasyonel sayılar, rasyonel olmayan sayılardır... Rasyonel sayılar ise $\frac{p}{q}$ şeklinde yazıldı ̆̆ında $(p, q)=1$ olan sayılardır.

Matematik öğretmenlerinin rasyonel ve irrasyonel sayılardan oluşan bir sayı kümesindeki sayıların hangi sayı kümesine ait olduklarını tanımalarına yönelik bulgular Tablo 3 de sunulmuştur. Tablo incelendiğinde öğretmenlerin verilen sayı kümesindeki bazı sayılarla ilgili yanılgılarının ve tereddütlerinin olduğu görülmektedir. Öğretmenlerin güçlük yaşamasında özellikle $\pi$ sayısının ve irrasyonel sayıların farklı gösterimlerinin etkili olduğu söylenebilir. Ayrıca öğretmenlerin verilen sayıları rasyonel veya irrasyonel olarak sınıflamalarında kavramlarla ilgili yaptıkları tanımların etkili olduğu görülmüştür. Özellikle $\frac{3}{\pi}$ ve $1,92713 \ldots$ sayılarının rasyonel sayı olarak gösterilmesi buna örnek oluşturmaktadır. Bununla birlikte öğretmenlerin derslerinde $\pi=\frac{22}{7}$ şeklinde kullanımlarından kaynaklanan bir yanılgı da görülmüştür. $\mathrm{Bu}$ yüzden $\frac{22}{7}$ sayısı irrasyoneldir şeklinde yanıtlar verilmiştir. Bazı öğretmenlerin ise $\sqrt{36}, 3+\sqrt{2}$ sayılarının rasyonel ya da irrasyonel olmasına karar veremedikleri gözlenmiştir. Bununla ilgili aşağıda Ö1, Ö2, Ö3, Ö6 ve Ö8 kodlu öğretmenlerin görüşlerine yer verilmiştir.

Tablo 3

Öğretmenlerin Verilen Bir Sayı Kümesindeki Sayıların Rasyonel ya da Irrasyonel Olduğunu Tanıma Durumları

\begin{tabular}{lcc}
\hline Doğru Yapanlar & Yanılgıya Düşenler & Yanılgıуa Sebep olan Sayılar \\
\hline Ö1, Ö3, Ö4, Ö7 & Ö2, Ö5, Ö6, Ö8 & $\frac{22}{7}, \frac{3}{\pi}, \sqrt{36}, 3+\sqrt{2}, 1,92713 \ldots$ \\
\hline
\end{tabular}


Ö1: Burada $\frac{a}{b}$ şeklinde yazllabilenler rasyonel diğerleri ise irrasyonel olur. Ama burada $3+\sqrt{2}$ den emin değilim. Rasyonel ve irrasyonel sayının toplamı... [Düşünüyor] ... bu sayı rasyonel de olabilir bundan tam emin olamıyorum.

Ö2: Şöyle rasyonel ve irrasyonel şeklinde iki küme olarak yazayım. $A=$ $\left\{-5, \frac{1}{3}, 1.255 \ldots, \sqrt{36}, 3.14\right\}, \quad A \subset \mathbb{Q} \quad$ olsun $\ldots B \subset \mathbb{Q}^{\prime} \quad$ olsun... $B=$ $\left\{\frac{22}{7}, 3 \sqrt{3}, 1.192713 \ldots, 3+\sqrt{2}, \sqrt[3]{3}, \frac{3}{\pi}\right\}$ olur. Ama $\frac{22}{7}$ sayısını $\pi$ olarak düşündüğüm için irrasyonel sayılar arasında yazdım. Çünkü bazı kitaplarda bu sayı $\pi$ ile eşit olarak alınıyor. Ama neden bu şekilde düşünüldüğ̈̈nü bilmiyorum. Bu sayının irrasyonel mi yoksa rasyonel mi olduğundan çokta emin değilim.

Ö3: Bunlart ayrı ayrı kümeler olarak yazayım... Irrasyonel sayılar: $\left\{3 \sqrt{3}, 1.192713 \ldots, 3+\sqrt{2}, \sqrt[3]{3}, \frac{3}{\pi}\right\}$ olur. Virgülden sonra tahmin edilemeyen ya da kök dışına çıkamayan sayllara irrasyonel diyoruz... Rasyonel olanları da yazayım... Rasyonel sayılar: $\left\{-5, \frac{22}{7}, \frac{1}{3}, 1.2555 \ldots, \sqrt{36}, 3.14\right\}$ Burada $\frac{22}{7}$ sayısı $\pi$ değildir. Çocuklar sürekli bunu sordukları için ben bölme işlemi yapma gereği duydum ... $\pi$ sayısı ile karşılaştırdığımda aynı olmadıklarını gördüm.

Ö6: $\quad$ Şimdi... Rasyonel $\quad$ olanlar: $\quad\left\{-5, \frac{22}{7}, \frac{1}{3}, 1.192713 \ldots, \sqrt{36}, \frac{3}{\pi}\right.$, $3.14,1.2555 \ldots\}$ şeklindedir. Çünkü 1.192713 ... sayısının virgülden sonrası sürekli farklı da olsa paydasında da bir sayı vardır ve yine bu sayı da $\frac{a}{b}$ şeklinde yazılabilir... O yüzden bence rasyoneldir. Aynı şekilde düşündüğümüzde; 1.2555 ... sayısı da rasyoneldir. Aralarında asal olmasına aykırı bir durum da olmaz... $\frac{3}{\pi} \ldots$ [Düşünüyor]... Bence bu sayı da buradadır. Çünkü bu sayı için de pay ve payda aralarında asaldır. Ama sonsuza kadar giden bir $\pi$... [Düşünüyor] ... Bence rasyoneldir... Çünkü rasyonel olma şartlarına aykırı bir şey göremiyorum. En kötü ihtimalle sadeleştirme yaparak aralarında asal hale getirilebilir. Sadeleştirdiğimizde ise bence olur. Irrasyonel olanlar: $\{3 \sqrt{3}, 3+$ $\sqrt{2}, \sqrt[3]{3}\}$ olur. Bu sayılar tam olarak belli değildir. Kök dışına da çıkarılamazlar.

Ö8: Rasyonel sayllar: $\left\{-5, \frac{1}{3}, 1.2555 \ldots, \sqrt{36}, 3.14\right\} \ldots \quad \frac{22}{7} \quad$ bunu bölmek gerekiyor... Bu sayı devirli mi yoksa devretmeyen bir sayı mı bakmamı gerekir... [Bölme işlemi yapıyor]... Sanki $\pi$ sayısı gibi geldi bana... $\pi$ sayısı da rasyonel olmayan irrasyonel olan bir sayıdır. Böldüğ̈̈müz de $\frac{22}{7}=3,14$ olur. [Bölme işlemini 3,14 sayısını görünce bıraklyor, devam etmiyor] ... Dolayısıyla bu sayı $\pi$ saylst... $\pi$ sayısı da irrasyonel bir sayıdır. 1.2555 ..., sayısında 5 devrediyor... Devirli sayıları da rasyonel şekilde yazabildiğimiz için rasyoneldir. $\sqrt{36}$ sayısı kök dışına 6 olarak çıkabileceği için bu sayı rasyoneldir. 3.14 sayısı ondalıklı rasyonel bir sayldır. Irrasyonel saylar: $\left\{\frac{22}{7}, 3 \sqrt{3}, 1.192713 \ldots, 3+\sqrt{2}, \sqrt[3]{3}, \frac{3}{\pi}\right\}$ olur. $3 \sqrt{3}$ bir rasyonelle bir irrasyonel sayının çarpımı olduğu için irrasyoneldir. 1.192713 ..., bu sayıda devreden bir sayı göremediğim için irrasyoneldir. $3+\sqrt{2}$ de irrasyoneldir. Çünkü bir rasyonel sayı ile bir irrasyonel sayının toplamı da yine irrasyoneldir. $\sqrt[3]{3}$ sayısı da kök dışına çıkamadı̆̆ için irrasyoneldir. $\frac{3}{\pi}$ irrasyoneldir. Çünkü $\pi$ sayısı irrasyonel olduğu için rasyonel bir sayıyla bölümü 
yine irrasyonel olur. Rasyonel bir sayı ile irrasyonel bir sayının toplami, farkı, çarpımı ve bölümü her zaman irrasyonel olur.

\section{İrrasyonel Sayıların Sayı Doğrusu ve Sayı Dizisindeki Yerleri İçin Öğretmenlerin Kullandıkları Stratejiler}

Matematik öğretmenlerinin $\sqrt{2}$ sayısının sayı doğrusu üzerindeki tam yerini gösterirken kullandıkları stratejilere yönelik bulgular Tablo 4 te sunulmuştur. Tablo incelendiğinde öğretmenlerin $\sqrt{2}$ sayısının sayı doğrusu üzerindeki yerini belirlerken, Geometrik yaklaşım, Yaklaşık Değer/Ondalık Gösterim yaklaşımı ve Tahmini gösterim stratejilerini kullandıkları görülmektedir. Bu stratejiler içerisinde sadece Geometrik yaklaşımı kullanan öğretmenler Pisagor Teoremi yardımıyla $\sqrt{2}$ sayısının yerini tam olarak gösterebilmişlerdir. Ö4 ve Ö7 kodlu öğretmenler irrasyonel sayılar ile geometrik olarak uzunluk arasındaki ilişkiyi kurabildikleri için sonuca ulaştıkları söylenebilir. Ancak Yaklaşık değer/Ondalık gösterim yaklaşımıyla $\sqrt{2}$ sayısının yerini belirlemeye çalışan öğretmenler tam olarak sonuca ulaşamamışlardır. Sadece $\sqrt{2}$ sayısının yaklaşık değerlerinin gösterilebileceğini ama tam yerinin bulunamayacağını belirtmişlerdir. Benzer şekilde Tahmini gösterim stratejisini kullanan öğretmenlerin de $\sqrt{2}$ sayısının tam yerinin bulunamayacağını düşündükleri görülmüştür. Sadece " $1<\sqrt{2}<2$ aralığında bir yerdedir" şeklinde yanıtlar vermişlerdir. Dolayısıyla öğretmenlerin bir irrasyonel sayının sayı doğrusu üzerindeki tam yerini göstermekte güçlükler yaşadıkları belirlenmiştir. Aşağıda öğretmenlerin yanıtlarından örnekler verilmiştir.

Tablo 4

Öğretmenlerin $\sqrt{2}$ Sayısının Sayı Doğrusu Üzerindeki Yerini Gösterirken Kullandıkları Stratejiler

\begin{tabular}{|c|c|c|}
\hline Öğretmenler & Temalar & Öğretmen söylemleri \\
\hline Ö4, Ö7 & Geometrik Yaklaşım & $\begin{array}{l}\text { Pisagor teoremi ve yarıçapı } \sqrt{2} \text { olan bir çember } \\
\text { yardımıyla sayı doğrusu üzerindeki tam yerini } \\
\text { belirleriz. }\end{array}$ \\
\hline Ö5, Ö8 & $\begin{array}{l}\text { Yaklaşık Değer/Ondalık } \\
\text { Gösterim Yaklaşımı }\end{array}$ & $\begin{array}{l}\sqrt{2} \cong 1,4 \text { olduğundan yaklaşık olarak say1 } \\
\text { doğrusu üzerindeki yerini gösterebiliriz. }\end{array}$ \\
\hline $\begin{array}{l}\text { Ö1, Ö2, Ö3, } \\
\text { Ö6 }\end{array}$ & Tahmini Gösterim & $\begin{array}{l}1<\sqrt{2}<2 \text { aralığında bir sayıdır ama sayı } \\
\text { doğrusu üzerindeki tam yerini belirleyemeyiz. }\end{array}$ \\
\hline
\end{tabular}

Ö7: Yani ben bunu şu şekilde düşünüyorum... Kenarları 1 birim olan bir kare çizdiğimizde bu karenin köşegeninin uzunluğu $\sqrt{2}$ olur. Şimdi $\sqrt{2}$ yi yarıçap kabul eden bir çember çizebiliriz... Bu şekilde düşündüğ̈̈müzde tam $\sqrt{2}$ ye denk gelir... Bunu sayı doğrusuna nasıl taşıyabiliriz... [Düşünüyor]... Eksen olarak yapabiliriz... [Koordinat ekseni üzerinde gösteriyor] ... Şimdi $\sqrt{2}$ birimlik bir ölçü bulacă̆ız... Şimdi merkezi $(0,0)$ olan bir çember çizdiğimizde bu çemberin $x$ eksenini kestiği nokta $\sqrt{2}$ sayısının sayı doğrusu üzerindeki tam yeri olur. 
Ö8: $\sqrt{2}$ sayısını sayı doğrusu üzerinde tam yeri... Yok olmaz... Yaklaşık olarak gösterebiliriz. Yani belli bir rasyonel sayıdan küçüktür, belli bir rasyonel sayıdan büyüktür şeklinde yaklaşık olarak bulabiliriz. Şimdi $\sqrt{2}$ sayısını hangi iki sayı arasına konumlandirabiliriz... [Düşünüyor]... $\quad(1,1)^{2}=1,21 . ., \quad(1,2)^{2}=$ $1,44 \ldots,(1,4)^{2}=1,96 \ldots, \quad(1,5)^{2}=2,25$ eder... Yani $\sqrt{2}$ sayıs 1,4 ile 1,5 arasındadır diyebilirim. Yani $\left(\frac{14}{10}, \sqrt{2}, \frac{15}{10}\right)$ şeklinde bir yerde olacağını düşünüyorum.

Ö1: $\sqrt{2}$ sayısı irrasyonel olduğundan ve sayının kaç olduğunu tam olarak belirleyemediğimiz için sayı doğrusu üzerindeki yerini ancak tahmini olarak belirleyebiliriz. Sayı doğrusu üzerindeki yeri nerededir... [Düşünüyor] ... $\sqrt{2}$ nedir 1 ile 2 arasında bir yerde olması gerekir. Bir koordinat düzlemi çizeyim... $\sqrt{2}, 1$ ile 2 arasında bir yerde olduğuna göre $x$ ekseninde 1 ile 2 arasında ama 1 e daha yakın bir yerdedir. [Söylediklerini çiziyor]... Yani bu şekilde ancak tahmini olarak yerini belirleyebiliriz. Çünkü irrasyonel sayıların bir tanımında da virgülden sonraki basamakları sonsuza kadar devam ettiği için sayı doğrusu üzerinde tam bir noktayı temsil etmez. Dolayısıyla tam yerinin bulunamayacağını düşünüyorum. Sadece tahmini olarak gösterebiliriz.

Araştırmaya katılan öğretmenlerin tamamı iki irrasyonel sayı arasına her zaman başka bir irrasyonel sayının yazılabileceğini düşünmektedir. Matematik öğretmenlerinin iki irrasyonel sayı arasına her zaman başka bir irrasyonel sayı yazılabilmesine yönelik kullandıkları stratejiler Tablo 5 de sunulmuştur. Tablo incelendiğinde öğretmenlerin kullandıkları stratejilerin; Rasyonel Düşünme Yaklaşımı, Ondalık Sayı Yaklaşımı, Kök Kullanma Yaklaşımı ve Sezgisel Gösterim şeklinde olduğu görülmektedir. Ancak öğretmenlerin yanıtları derinlemesine incelendiğinde $\sqrt{2}$ ile $\sqrt{3}$ arasına başka bir irrasyonel sayı yazılırken kullanılan stratejiler içerisinde en geçerli olanın Ondalık Sayı Yaklaşımı olduğu görülmüştür. Bu şekilde düşünen öğretmenler $\sqrt{2}$ ve $\sqrt{3}$ sayılarının yaklaşık ondalık sayı değerlerini doğru bir şekilde oluşturarak bu iki sayı arasında başka bir irrasyonel sayı yazabilmişlerdir. Ancak Tablo da görüldüğü üzere, Rasyonel Düşünme Yaklaşımı ve Kök Kullanma Yaklaşımı stratejilerini kullanan öğretmenlerin yazdıkları irrasyonel sayıların istenilen aralıkta olmadığı belirlenmiştir. Dolayısıyla bu şekilde düşünen öğretmenlerin irrasyonel sayıların yaklaşık değerlerini oluşturmada güçlük yaşadıkları görülmüştür. Sezgisel gösterim stratejisini kullanan öğretmenin ise yanıtı doğru olmakla birlikte araştırmacı tarafından istenilen aralıkta değildir. Ö3 kodlu öğretmen iki irrasyonel sayı arasında her zaman başka bir irrasyonel sayı olacağını belirterek yanıtını $\sqrt{2}<\sqrt{3}<\sqrt{7}$ şeklinde örneklendirmiştir. Örnek yanıtlar aşağıda sunulmuştur. 
Tablo 5

Öğretmenlerin İki Irrasyonel Sayı Arasına Bir Irrasyonel Sayı Yazarken Kullandıkları Stratejiler

\begin{tabular}{|c|c|c|}
\hline Öğretmenler & Temalar & Örnek Yanitlar \\
\hline Ö1, Ö2, Ö4 & $\begin{array}{l}\text { Rasyonel Düşünme } \\
\text { Yaklaşımı }\end{array}$ & Ö1: $\sqrt{2}<\frac{\sqrt{3}-\sqrt{2}}{2}<\sqrt{3}$, Ö $4: \sqrt{2}<\frac{\sqrt{5}}{2}<\sqrt{3}$ \\
\hline Ö6, Ö7, Ö8 & Ondalık Sayı Yaklaşımı & $\begin{array}{l}\text { Ö8: } \quad \sqrt{2}=\left(\frac{14}{10}, \frac{15}{10}\right), \quad \sqrt{3}=\left(\frac{17}{10}, \frac{18}{10}\right) \text { ise } \\
\left(\frac{15}{10}, \frac{17}{10}\right) \text { arasinda sonsuz tane irrasyonel say1 } \\
\text { vardır. }\end{array}$ \\
\hline Ö5 & Kök Kullanma Yaklaşımı & Ö5: $\sqrt{2}<\sqrt[3]{9}<\sqrt{3}$ \\
\hline Ö3 & Sezgisel Gösterim & Ö3: $\sqrt{2}<\sqrt{3}<\sqrt{7}$ \\
\hline
\end{tabular}

Ö2: $\sqrt{2}$ ile $\sqrt{3}$ arasında mesela $\sqrt{\frac{5}{2}}$ yazabiliriz... Yani $\sqrt{2}<\sqrt{\frac{5}{2}}<\sqrt{3}$ şeklinde yazabiliriz. Çünkü her iki rasyonel sayı arasında bir rasyonel sayı varsa her iki irrasyonel sayı arasında da bir irrasyonel sayı bulunabilir. Çünkü bu rasyonel sayıların köklü şekilde yazılımlarının olabileceğini düşünüyorum.

Ö7: Yani $\sqrt{2}+\cdots$ şeklinde bir şey yazabiliriz... Yani $\sqrt{3}$ olmayacak şekilde yapacă̆ımı her ekleme yine bir irrasyonel sayı olur... Mesela 0,00 ... bir şey ekleyebilirim... Yani $\sqrt{3}$ e yaklaşana kadar bir sürü say yazabilirim. $\sqrt{3}$ ten daha büyük olup olmadığını da sayıların karelerini alıp büyüklüklerini karşılaştırarak karar verebilirim. Yaklaşık değer olarak... Evet bu şekilde yazllabilir. $\sqrt{2}$ ile $\sqrt{3}$ arasında... $\sqrt{2}<\sqrt{2}+0,01<\sqrt{3}$ şeklinde olabilir...

Ö5: $\sqrt{2}$ ile $\sqrt{3}$ arasında... [Düşünüyor] ... $\sqrt{2}$ ile $\sqrt{3}$ arasinda... $\sqrt{2}, \sqrt[3]{9}, \sqrt{3}$ olur... Hepsinin küpünü alırsak yazdığım sayının bu iki sayı arasında kaldığı görülür.

Ö3: Mesela $\sqrt{2}$ ile $\sqrt{7}$ arasında düşünürsek; $\sqrt{3}$ bu aralıktadır...

Matematik öğretmenleri iki rasyonel sayı arasında her zaman başka bir rasyonel sayının yazılabileceğini belirtmişlerdir. Öğretmenlerin iki rasyonel sayı arasına başka bir rasyonel sayı yazarken kullandıkları stratejiler Tablo 6 da verilmiştir. Araştırmacı tarafından öğretmenlerden $\frac{1}{3}$ ile $\frac{1}{2}$ arasında bir rasyonel sayı yazmaları istendiğinde sadece Ö7 kodlu öğretmen bu aralığın dışında yanıt vermiştir. Tablo incelendiğinde öğretmenlerin kullandıkları stratejilerin; Genelleme Yaklaşımı, Ondalık Sayı Yaklaşımı, Ortadaki Sayıyı Bulma Yaklaşımı ve Sezgisel Gösterim şeklinde olduğu görülmektedir. Öğretmenlerin rasyonel iki sayı arasına başka bir rasyonel sayı yazarken irrasyonel sayıların aksine güçlük yaşamadıkları gözlenmiştir. Öğretmenlerin kullandıkları stratejilerle ilgili örnek yanıtları aşağıda sunulmuştur. 
Tablo 6

Öğretmenlerin İki Rasyonel Sayı Arasına Bir Rasyonel Sayı Yazarken Kullandıkları Stratejiler

\begin{tabular}{lll}
\hline Öğretmenler & \multicolumn{1}{c}{ Temalar } & \multicolumn{1}{c}{ Örnek Yanıtlar } \\
\hline Ö1, Ö8 & Genelleme Yaklaşımı & $\begin{array}{l}\text { Ö8: İki rasyonel sayının tam ortasındaki } \\
\text { sayıyı bulabilir ve bu işlemi sonsuz defa } \\
\text { tekrar edebiliriz. }\end{array}$ \\
Ö2, Ö3, Ö6 & Ondalık Sayı Yaklaşımı & Ö6: $\frac{1}{3}=0, \overline{3}$ ve $\frac{1}{2}=0,5$ ise $\frac{1}{3}<0,4<\frac{1}{2}$ olur. \\
Ö4, Ö5 & Ortadaki Sayıyı Bulma & Ö4: Bu iki sayıyı toplayıp ikiye bölersek; $\frac{1}{3}<$ \\
& Yaklaşımı & $\frac{5}{12}<\frac{1}{2}$ olur. \\
Ö7 & Sezgisel Gösterim & Ö7: Mesela $\frac{1}{2}$ ile $\frac{1}{4}$ arasında $\frac{1}{3}$ yazarım... \\
\hline
\end{tabular}

Ö1: Mesela $\frac{1}{2}$ ile $\frac{1}{3}$ arasinda bir tane rasyonel sayl yazabiliriz. Ya da tam ortadaki bunlar arasina yine bir tane daha yazabiliriz... Aynı şekilde daha da daraltarak devam edip hepsinin arasina bir tane daha rasyonel say yazabiliriz. Yani bu aralıkta sonsuz tane sayı olduğu için her zaman araya başka sayılar yazabiliriz.

Ö3: Ya kesinlikle yazılabilir. Bunları ondalıklı sayı olarak düşündüğ̈̈müzde... $\frac{1}{3}=0,33 \ldots$ ve $\frac{1}{2}=0,5$ olduğundan $0,4=\frac{2}{5}$ bu iki sayı arasındadır. Dolayıslyla iki rasyonel sayı arasına başka bir rasyonel sayı yazabiliriz.

Ö5: $\frac{1}{3}$ ile $\frac{1}{2}$ arasında bir rasyonel sayl... [Düşünüyor] ... Bu arada da $\frac{1}{3}=\frac{4}{12}, \frac{1}{2}=$ $\frac{6}{12}$ olduğundan $\frac{5}{12}$ olabilir. $\frac{1}{3}<\frac{5}{12}<\frac{1}{2}$ olur.

Ö7: Ben onu şöyle düşündüm... [Sayı doğrusu üzerinde gösteriyor] ... Mesela $\frac{1}{2}$ ile $\frac{1}{4}$ arasında $\frac{1}{3}$ yazarım... Bu şekilde daha kolay görülebiliyor. Böyle düşündüğ̈̈müzde $\frac{1}{3}$ ile $\frac{1}{5}$ arasında da $\frac{1}{4}$ yazabiliriz...

Matematik öğretmenleri iki rasyonel sayı arasında her zaman bir irrasyonel sayının yazılabileceğini belirtmişlerdir. Öğretmenlerin iki rasyonel sayı arasına bir irrasyonel sayı yazarken kullandıkları stratejiler Tablo 7 de sunulmuştur. Tablo incelendiğinde öğretmenlerin kullandıkları stratejilerin; Kök Alma Yaklaşımı, Ondalık Sayı Yaklaşımı ve Sezgisel Gösterim şeklinde olduğu görülmektedir. Öğretmenlerin kullandıkları stratejiler incelendiğinde Kök alma ve Ondalık sayı yaklaşımlarının kullanıldı̆̆ı yanıtların istenilen aralıkta ve doğru olduğu görülmüştür. Kök alma yaklaşımının kullanıldığı yanıtlarda $\frac{1}{3}$ ile $\frac{1}{2}$ arasında $\frac{1}{\sqrt{5}}$ şeklinde köklü irrasyonel sayıların yazıldığı, Ondalık sayı yaklaşımının kullanıldığ 1 yanıtlarda ise $\frac{1}{3}<0,358 \ldots<\frac{1}{2}$ şeklinde virgülden sonrası sonsuz ve tekrarsız olan irrasyonel sayıların yazıldığı görülmüştür. Ancak Sezgisel gösterim stratejisinin kullanıldığ1 yanıtlarda net bir cevabın verilemediği tespit edilmiştir. Ö8, Ö7 ve Ö4 kodlu öğretmenlerin kullandıkları stratejilerle ilgili örnek yanıtları aşağıda sunulmuştur. 
Tablo 7

Öğretmenlerin İki Rasyonel Sayı Arasına Bir Irrasyonel Sayı Yazarken Kullandıkları Stratejiler

\begin{tabular}{lcl}
\hline Öğretmenler & \multicolumn{1}{c}{ Temalar } & \multicolumn{1}{c}{ Örnek Yanıtlar } \\
\hline Ö5, Ö6, Ö8 & Kök Alma Yaklaşımı & Ö5: $\frac{1}{3}$ ile $\frac{1}{2}$ arasında... Mesela burada $\frac{1}{2}=\frac{1}{\sqrt{4}}$ \\
& olduğuna göre bu arada biz $\frac{1}{\sqrt{5}}$ yazabiliriz. \\
Ö2, Ö3, Ö7 & Ondalık Say1 Yaklaşımı & Ö3: $\frac{1}{3}=0, \overline{3}$ ve $\frac{1}{2}=0,5$ ise $\frac{1}{3}<0,358 \ldots<\frac{1}{2}$ \\
& & şeklinde virgülden sonras1 sonsuz ve düzensiz \\
& devam eden bir say1 yazabiliriz. \\
Ö1, Ö4 & Sezgisel Gösterim & Ö1: Yani bu aralikta sonsuz tane sayı olduğu için \\
& & her zaman araya başka sayılar yazabiliriz. \\
\hline
\end{tabular}

Ö8: $\frac{1}{3}$ ile $\frac{1}{2}$ arasında... [Düşünüyor] ... Şimdi paylar eşit olduğu için biz paydalara bakarız... 2 den büyük 3 ten küçük bir irrasyonel sayı bulabilirsek ve payı 1 olacak şekilde paydaya bu sayıyı yazdığımızda olacaktır. 2 den büyük irrasyonel sayımız... $2^{2}=4 \ldots,(\sqrt{5})^{2}=5$ olduğuna göre; $3>\sqrt{5}>2$ olur. Dolayısıla $\frac{1}{\sqrt{5}}$ olur. Yani $\frac{1}{3}<\frac{1}{\sqrt{5}}<\frac{1}{2}$ olur. Çünkü karelerini aldı̆̆ımızda eşitsizlik $\frac{1}{9}<\frac{1}{5}<\frac{1}{4}$ şeklinde korunuyor. Yani bu şekilde sayllar bulunabilir.

Ö7: Yine yazarız... $\frac{1}{2}=0,5$ ve $\frac{1}{3}=0,333 \ldots$ şeklinde ondalıkl olarak düşünürsek; 0,5, 0,475 ..., 0,333 ... şeklinde virgülden sonrası düzensiz şekilde sonsuza kadar devam eden bir sayı yazabilirim. Ondalıklı olarak düşündügü̈müzde daha rahat görülebiliyor.

Ö4: Olmalıdır... Ama bunu net olarak bulabilir miyiz?... Düşünmek gerek...

Matematik öğretmenleri iki irrasyonel sayı arasında her zaman bir rasyonel sayının yazılabileceğini belirtmişlerdir. Öğretmenlerin iki irrasyonel sayı arasına bir rasyonel sayı yazarken kullandıkları stratejiler Tablo 8 de sunulmuştur. Tablo incelendiğinde öğretmenlerin kullandıkları stratejilerin; Yaklaşık Değer Yaklaşımı, Kare Alma Yaklaşımı ve Sezgisel Gösterim şeklinde olduğu görülmektedir. Öğretmenlerin kullandıkları stratejiler incelendiğinde Yaklaşık Değer ve Kare Alma Yaklaşımları ile istenilen aralıkta ve doğru yanıtların verildiği görülmüştür. Yaklaşık Değer yaklaşımına göre $\sqrt{2}<\frac{3}{2}<\sqrt{3}$, Kare alma yaklaşımına göre ise $\sqrt{2}<1,6<\sqrt{3}$ şeklinde yanıtların verildiği görülmektedir. Ancak Sezgisel gösterim yaklaşımını kullanan öğretmenlerin "Yine 1 ile 2 arasındaki bir rasyonel sayı bu aralıkta olur." şeklinde tahmini yanıtlar verdikleri belirlenmiştir. Ö5, Ö6 ve Ö7 kodlu öğretmenlerin kullandıkları stratejilerle ilgili örnek yanıtları aşağıda sunulmuştur. 
Tablo 8

Öğretmenlerin İki Irrasyonel Sayı Arasına Bir Rasyonel Sayı Yazarken Kullandıkları Stratejiler

\begin{tabular}{|c|c|c|}
\hline Öğretmenler & Temalar & Örnek Yanitlar \\
\hline Ö1, Ö3, Ö5, Ö8 & $\begin{array}{l}\text { Yaklaşık Değer } \\
\text { Yaklaşımı }\end{array}$ & $\begin{array}{l}\text { Ö1: Mesela } \sqrt{2}=1,41 \text { ve } \sqrt{3}=1,7 \text { yaklaşık } \\
\text { değerleri olduğuna göre bu arada rasyonel bir } \\
\text { sayı mutlaka vardır. Mesela } \frac{3}{2} \text { rasyonel sayısı bu } \\
\text { aradadır. }\end{array}$ \\
\hline Ö2, Ö7 & Kare Alma Yaklaşımı & $\begin{array}{l}\text { Ö2: Karelerini alırsam } 2<x^{2}<3 \text { olacak } \\
\text { şekilde bir rasyonel sayı yazmalıyım... Buradan } \\
\text { 1,6 sayısını yazabiliriz. }\end{array}$ \\
\hline Ö4, Ö6 & Sezgisel Gösterim & $\begin{array}{l}\text { Ö4: Bu sayıların yaklaşık değerlerini bulup } \\
\text { araya bir rasyonel sayı rahatlıkla sıkıştırılabilir. } \\
\text { Her ikisi de } 1 \text { ile } 2 \text { arasındadır... Yine } 1 \text { ile } 2 \\
\text { arasındaki bir rasyonel sayı bu aralıkta olur. }\end{array}$ \\
\hline
\end{tabular}

Ö5: Iki irrasyonel arasında her zaman vardır... Mesela $\sqrt{2}$ ile $\sqrt{3}$ arasında bir rasyonel sayl yazmayl denersem $\odot$... Simdi $\sqrt{2}=1,4$ ve $\sqrt{3}=1,7$ civarinda birer sayı oldukları için ben bu arada $\frac{3}{2}$ yazabilirim. Yani $\sqrt{2}<\frac{3}{2}<\sqrt{3}$ şeklinde yazllabilir...

Ö7: Onu da yazarlz... [Düşünüyor]... Mesela yine $\sqrt{2}$ ile $\sqrt{3}$ arasında bir rasyonel sayı yazmayı denesek... Yani $\sqrt{2}<x<\sqrt{3}$ şeklinde bir $x$ sayısını arlyorum... Karelerini alırsak... $2<x^{2}<3$ olur... Şimdi karesi 2 ile 3 arasında olan bir rasyonel sayı arlyorum... Buradan 1,7 gibi bir sayı olabilir...

Ö6: Bilemiyorum ki... [Düşünüyor]... Yani tam olarak yaklaşık değerlerini belirleyemediğimden yazacă̆ım rasyonel sayılar bu iki sayı arasında olmayabilir... [Düşünüyor]... Aklıma bir şey gelmiyor. Mesela şunu bilsem... $\sqrt{2}=1,2$ ve yine $\sqrt{3}=1,8$ şeklinde yaklaşık değerlerini bilsem... Hemen bu araya bir rasyonel sayı yazabilirim. Ama yaklaşık değerlerini tam olarak bilmediğim için 1 ile 2 arasında bir rasyonel sayı olur diyebilirim.

\section{Öğretmenlerin İrrasyonel ve Rasyonel Sayılarla Yapılan İşlemlere Yönelik Düşünceleri}

Çalışmanın son araştırma problemi, matematik öğretmenlerinin irrasyonel ve rasyonel sayılar kümelerinin toplama ve çarpma işlemlerine göre kapalı olup olmadığı hakkındaki yanıtlarını incelemektir. Matematik öğretmenlerinin irrasyonel sayıların toplama işlemine göre kapalı olup olmadığına yönelik yanıtları Tablo 9 da görülmektedir. Tablo incelendiğinde 3 (Ö1, Ö7, Ö8) öğretmen irrasyonel sayılar kümesinin toplama işlemine göre kapalı olmadığını, 5 (Ö2, Ö3, Ö4, Ö5, Ö6) öğretmen ise kapalı olduğunu belirtmiştir. Öğretmenlerin iki irrasyonel sayının toplamının her zaman irrasyonel olmayacağını göstermek için $\sqrt{2}+(-\sqrt{2})=0$ şeklinde örnekler verdikleri görülmüsştür. Bununla birlikte bu öğretmenlerin toplama işlemine göre kapalı olmayan irrasyonel sayılar kümesi üzerinde toplama işleminin nasıl yapıldığına 
yönelik açıklayıcı yanıtlar veremedikleri gözlenmiştir. Öğretmenler, irrasyonel sayılar kümesinde bu işlemi nasıl yaptıklarını bilmediklerini (Ö1, Ö7) ya da kabul olarak düşünülebileceğini (Ö8) ifade etmişlerdir. İki irrasyonel sayının toplamının her zaman irrasyonel olduğunu düşünen öğretmenler ise bu durumu sağlamayan aksi bir örneğin bulunamayacağını belirtmişlerdir. Dolayısıyla $\sqrt{2}$ ve $\sqrt{3}$ şeklinde iki irrasyonel sayının toplamı olan $\sqrt{2}+\sqrt{3}$ sayısının da irrasyonel olduğu şeklinde örnekler vermişlerdir. Ö1 ve Ö3 kodlu öğretmenlerin örnek yanıtları aşağıda sunulmuştur.

Tablo 9

Öğretmenlerin İki İrasyonel Sayının Toplamının Sonucuna Yönelik Yanıtları

\begin{tabular}{|c|c|c|}
\hline Öğretmenler & Toplam Sonucu & Örnek Yanitlar \\
\hline Ö1, Ö7, Ö8 & $\begin{array}{l}\text { Her zaman irrasyonel } \\
\text { değildir } \\
\text { Toplam sonucunun neden } \\
\text { her zaman irrasyonel } \\
\text { olmadığ1 ile ilgili Ö1 ve Ö7 } \\
\text { bilmediklerini, Ö8 ise bu } \\
\text { durumun bir kabul } \\
\text { olduğunu belirtmistir. }\end{array}$ & $\begin{array}{l}\text { Ö7: Mesela } \sqrt{2}-\sqrt{2}=0 \text { veya }(\sqrt{5}+2)- \\
\sqrt{5}=2 \text { olur. Böyle olduğundan her zaman } \\
\text { irrasyonel sayı olmaz. Yani irrasyonel olduğu } \\
\text { durumlar da vardır... Verdiğim örneklerde } \\
\text { olduğu gibi rasyonel olduğu durumlarda } \\
\text { vardır. }\end{array}$ \\
\hline $\begin{array}{l}\text { Ö2, Ö3, Ö4, } \\
\text { Ö5, Ö6 }\end{array}$ & Her zaman irrasyoneldir & $\begin{array}{l}\text { Ö5: Yani aklıma gelen aksi bir örnek yok... } \\
\text { Mesela } \sqrt{2} \text { ile } \sqrt{3} \text { sayıları irrasyonel olduğu } \\
\text { için toplamları } \sqrt{2}+\sqrt{3} \text { da irrasyonel çıar } \\
\text { diye düşünüyorum. Yani iki irrasyonel } \\
\text { sayının toplamından bir rasyonel sayı elde } \\
\text { edilebilir mi?... [Düşünüyor]... Edilemez } \\
\text { bence... }\end{array}$ \\
\hline
\end{tabular}

Ö1: İki irrasyonel sayının toplamı her zaman irrasyonel olabilir... [Düşünüyor] ... Mesela $\sqrt{2}$ ile $\sqrt{3}$ sayılarını topladığımızda $\sqrt{2}+\sqrt{3}$ bir irrasyonel sayıdır. Peki başka iki irrasyonel saylyı topladığımızda sonuç rasyonel olabilir mi?... [Düşünüyor]... Şimdi $\sqrt{2}$ irrasyonel ve $-\sqrt{2}$ irrasyonel olmak üzere $\sqrt{2}+$ $(-\sqrt{2})=0$ olur ve 0 rasyoneldir. O zaman aksi bir örnek bulmuş oluruz. Dolayısıla her iki irrasyonel sayının toplamı her zaman irrasyonel değildir.

M: Toplama işleminin irrasyonel sayılar kümesi üzerinde kapalı olmadiğını gördük. Dolayısılla toplama işlemi irrasyonel sayllar kümesi üzerinde tanımlı değildir. Peki, o zaman bu işlemi irrasyonel sayılar kümesi üzerinde nasıl yapabiliriz? Açıklayınız.

Ö1: Ama irrasyonel sayılar kümesi kapalıdır. Ama toplama işlemine göre kapalı olmadı... [Düşünüyor] ... Evet, kapalılık özelliği yoksa o işlem tanımlı olmuyor. $O$ zaman biz bunu kapalıdır diye kabul edip mi yapıyoruz acaba... Ama sonuç her zaman irrasyonel çıkmıyor... O zaman ya $-\sqrt{2}$ irrasyonel olmaz ya da bir çelişki vardır $\odot$... Bilemiyorum... Yani kapalı olması lazım ama biz hep iki irrasyonel 
saylyı topları... Ama kapalılık olmadan yapıyoruz, nedenini hiç düşünmemiştim ... Burada bir karışıklık var ama sebebini bilemiyorum.

Ö3: Ikki irrasyonel sayının toplamı her zaman irrasyonel sayı mıdır?... [Düşünüyor]... Toplamı sanırım evet... Var mıdır aksi diye düşünüyorum... Mesela $\sqrt{2}+\sqrt{2}=2 \sqrt{2}$ olur. Benzer şekilde $\sqrt{3}$ ile de denesek hep irrasyonel olur. Dolayısiyla her zaman irrasyonel olur.

Matematik öğretmenleri iki irrasyonel sayının çarpımının sonucunun her zaman irrasyonel olmayacağını belirtmişlerdir. Öğretmenler yanıtlarını $\sqrt{2} \cdot \sqrt{2}=2$ şeklinde örneklendirerek aksi örnekler sunmuşlardır. Öğretmenlerin verdikleri yanıtlar derinlemesine incelendiğinde köklü sayılarda bu tip işlemlerin sıklıkla yapılmasının doğru yanıt verilmesini etkilediği görülmüştür. Ancak öğretmenler tarafından irrasyonel sayılar kümesi üzerinde çarpma işleminin kapalı olmadığı bilinmesine rağmen bu işlemin irrasyonel sayılar kümesinde nasıl yapıldı̆̆ı sorulduğunda öğretmenlerin yanıt vermekte güçlük yaşadıkları gözlenmiştir. Öğretmenlerin irrasyonel sayılar kümesi üzerinde çarpma işlemini nasıl yaptıklarına yönelik yanıtları Tablo 10 da sunulmuştur. Tabloya göre öğretmenlerin irrasyonel sayılar kümesi üzerinde çarpma işlemini yaparken; Reel sayı düşünürüz, Üslü/köklü sayı olarak düşünürüz, Kabuldür ve Bilmiyorum şeklinde düşündükleri görülmektedir. Bu kategoriler incelendiğinde ise sadece Ö2 ve Ö3 kodlu öğretmenlerin çarpma işleminin nasıl yapıldığıyla ilgili düşüncelerinin geçerli olduğu görülmüştür. Bu öğretmenler iki irrasyonel sayının çarpımının irrasyonel sayılar yerine reel sayılar üzerinde tanımlanması gerektiğini ve ancak bu şekilde kapalı bir işlem tanımlanabileceğini ifade etmişlerdir. Bununla birlikte diğer öğretmenlerin üslü/köklü ifadelerle yaptıkları açıklamalar, kabul olabileceği ya da bilmiyorum şeklindeki yanıtlarının açıklayıcı olmadığı görülmektedir. Dolayısıyla öğretmenlerin irrasyonel sayılar kümesi üzerindeki çarpma işleminin kapalı olmamasına rağmen bu küme üzerinde nasıl yapıldığını açıklamakta güçlük yaşadıkları tespit edilmiştir. Ö2, Ö1 ve Ö6 kodlu öğretmenlerin örnek yanıtları aşağıda sunulmuştur.

Tablo 10

Öğretmenlerin İrasyonel Sayılar Kümesi Üzerinde Çarpma İşlemini Yönelik Yanıtları

\begin{tabular}{ll}
\hline Öğretmenler & Çünkü... \\
\hline Ö2, Ö3 & Reel sayı düşünürüz \\
& \\
Ö1, Ö5 & $\begin{array}{l}\text { Üslü/köklü sayı olarak } \\
\text { düşünürüz }\end{array}$
\end{tabular}

Örnek Yanitlar

Ö3: Reel sayılar kümesi üzerinde yapıyoruz... Biz bu sayıları çarparken irrasyonel sayı olarak değil de daha genel olarak reel sayı diye düşünüyoruz.

Ö5: Çarpma işlemi normalde üslü sayılardan da yapılabilir. Tabi biz böyle öğretmiyoruz ama... Biz köklü sayıları öğretirken eğer köklerin dereceleri eşit ise içerideki sayıları çarpabiliriz şeklinde öğretiyoruz. Ama açıklamak gerekirse $\sqrt{3}=3^{\frac{1}{2}}$ olduğundan ve tabanlar eşitse üsler toplanacağ 1 için $3^{\frac{1}{2}} \cdot 3^{\frac{1}{2}}=3^{\frac{1}{2}+\frac{1}{2}}=3^{1}=3$ şeklinde 


\begin{tabular}{|c|c|c|}
\hline Öğretmenler & Çünkü... & Örnek Yanitlar \\
\hline & & $\begin{array}{l}\text { çarpabiliriz. Bu şekilde de kökten kurtulmuş olur. } \\
\text { Üs ifadesi tamsayı olduğu zaman zaten köklü sayı } \\
\text { olmuyor. }\end{array}$ \\
\hline & & $\begin{array}{l}\text { Ö8: O zaman bence kapalılık özelliğinin rasyonel } \\
\text { ve reel sayılar da geçerliliği vardır. İrrasyonel } \\
\text { sayılar için kapalılık özelliği yoktur demek ki... }\end{array}$ \\
\hline Ö8 & Kabuldür & $\begin{array}{l}\text { Bence irrasyonel sayılar üzerinde kapalılık } \\
\text { özelliğini sağlatmaya çalışmak bile önemsiz } \\
\text { oluyor... Çünkü hiçbir işlem için sağlamıyor. } \\
\text { [Düşünüyor]... Kabullerle yapıyoruz diye } \\
\text { düşünüyorum. }\end{array}$ \\
\hline Ö4, Ö6, Ö7 & Bilmiyorum & $\begin{array}{l}\text { Ö7: [Düşünüyor]... } \mathrm{Bu} \text { sorunun cevabını } \\
\text { bilemiyorum... Yani toplama ya da çarpma } \\
\text { işlemleri kapalı değil ama nasıl yaptığımızı } \\
\text { bilmiyorum. }\end{array}$ \\
\hline
\end{tabular}

Ö2: [Düşünüyor] ... Çok doğru kapalılık özelliği yok... Daha önce hiç dikkatimi çekmemişti... Yani işlemin nasıl yapıldığını biliyorum ama... Yani kapalılık özelliğine aykırı olmasına ră̆men nasıl yapıyoruz onu bilmiyorum. Ya da şöyle olabilir bu sayıların hepsini reel sayı düşünürsek hiçbir sorun kalmaz. Çünkü her irrasyonel sayı aynı zamanda bir reel sayıdır. Ayrıca reel sayılarda bütün işlemlere göre kapalı olduğundan bu sorun aşılmış olabilir.

Ö1: [Düşünüyor]... Köklü saylların özelliklerinden yararlanarak yapabiliriz... Mesela $\sqrt{2} \cdot \sqrt{8}=\sqrt{2.8}=\sqrt{16}=4$ olur. Yani köklü ifadeleri ortak kökte yazabildiğimiz için olabilir... Buradan da şöyle bir sonuç çıkarabiliriz... İrasyonel sayılarda kapalılı özelliği her zaman sağlanmayabilir...

Ö6: [Düşünüyor] ... Sonuçta irrasyonel bir sayı rasyonel olan bir sayının köklü halidir... Bunu düşünerek mi yapıyoruz acaba... Ya da irrasyonel sayılar için işlemin kapalı olmamasını göz ardı ederek mi yapıyoruz... Bilemedim... Ama bence kök ifadesinden yararlanıyoruz sanırım... Çünkü köklü bir ifadenin karesi alındığında sayımız dışarı çıkarılabilir hale gelir... Bu şekilde de işlemimizi yapabiliyor olabiliriz diye düşünüyorum... Yani bunun dışında aklıma başka da bir şey gelmiyor...

Matematik öğretmenleri irrasyonel sayılar kümesi üzerinde yapılan toplama işleminin kapalılığg ile ilgili güçlük yaşamalarına rağmen rasyonel sayılar kümesinin toplama işlemine göre kapalı olduğunu belirtmişlerdir. Öğretmenlerin iki rasyonel sayının toplamının sonucuna yönelik yanıtları Tablo 11 de sunulmuştur. Tabloya göre öğretmenlerin iki rasyonel sayının toplamının sonucunun rasyonel olduğunu; Aksi bir örnek yoktur, Sonuç hep $\frac{a}{b}$ şeklindedir, Pay ve payda tamsayıdır ve Rasyonel sayılar kapalıdır şeklinde göstermeye çalıştıkları görülmektedir. Dolayısıyla öğretmenler sıklıkla rasyonel sayıları işlemlerinde kullandıkları için bu küme ve üzerinde yapılan işlemler hakkında daha ayrıntılı düşünebildikleri söylenebilir. Bu yüzden iki rasyonel sayının toplamının sonucuyla ilgili beklenen yanıtlar verdikleri görülmektedir. Ö2 ve Ö4 kodlu öğretmenlerin örnek yanıtları aşağıda sunulmuştur. 
Tablo 11

Öğretmenlerin İki Rasyonel Sayının Toplamına Yönelik Yanıtları

\begin{tabular}{|c|c|c|}
\hline Öğretmenler & Çünkü... & Örnek Yanitlar \\
\hline Ö2, Ö3, Ö8 & Aksi bir örnek yoktur & 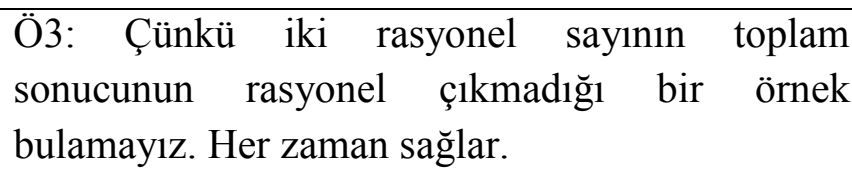 \\
\hline Ö4, Ö5, Ö6 & Sonuç hep $\frac{a}{b}$ şeklindedir & $\begin{array}{l}\text { Ö5: Çünkü rasyonel sayılarda toplama işlemi } \\
\text { yaparken payda eşitleyip direk olarak } \\
\text { topladığımız için sonuç her zaman } \frac{a}{b} \text { şeklinde } \\
\text { rasyonel olarak tanımladığımız sayılar oluyor. }\end{array}$ \\
\hline Ö7 & $\begin{array}{l}\text { Pay ve payda } \\
\text { tamsayıdır }\end{array}$ & $\begin{array}{l}\text { Ö7: Sonuçta tamsayılarla çalışıyoruz... Çünkü } \\
\text { rasyonel sayılarda pay ve payda tamsayıdır. O } \\
\text { yüzden sonuçta da bir tamsayı buluyorum. Her } \\
\text { tamsayı da bir rasyonel sayı olduğundan sonuç } \\
\text { hep rasyonel olur. }\end{array}$ \\
\hline Ö1 & $\begin{array}{l}\text { Rasyonel sayılar } \\
\text { kapalıdır }\end{array}$ & $\begin{array}{l}\text { Ö1: Çünkü rasyonel sayılarda toplama işleminin } \\
\text { kapalılık özelliği vardır. }\end{array}$ \\
\hline
\end{tabular}

Ö2: Evet... İki rasyonel sayının toplamı yine rasyonel bir sayıdır. Aksi bir örnek rasyonel sayılar için yoktur... Mesela $\frac{1}{2}+\frac{1}{3}=\frac{1}{6}$ olur ve bu tüm rasyonel sayılar içinde geçerlidir.

Ö4: Toplamı her zaman rasyoneldir... Çünkü iki rasyonel sayıyı toplarken paydalar eşitlenip paylar toplantyor... Her zaman $\frac{a}{b}$ şeklinde yine bir rasyonel sayl elde ediliyor.

Matematik öğretmenleri iki rasyonel sayının toplamında olduğu gibi iki rasyonel sayının çarpımının sonucunun da rasyonel olacağını belirtmişlerdir. Öğretmenlerin iki rasyonel sayının çarpımının sonucuna yönelik yanıtları Tablo 12 de sunulmuştur. Tabloya göre öğretmenlerin iki rasyonel sayının çarpımının sonucunun rasyonel olduğunu; Aksi bir örnek yoktur, Sonuç hep $\frac{a}{b}$ şeklindedir ve Rasyonel sayılar kapalıdır şeklinde göstermeye çalıştıkları görülmektedir. Dolayısıyla öğretmenlerin rasyonel sayılar kümesi üzerinde toplama işleminde olduğu gibi çarpma işleminde de kapalılık özelliğinin sağlandığının farkında oldukları tespit edilmiştir. Ö3 ve Ö5 kodlu öğretmenlerin iki rasyonel sayının çarpımının sonucuna yönelik örnek yanıtları aşağıda sunulmuştur. 
Tablo 12

Öğretmenlerin İki Rasyonel Sayının Çarpımına Yönelik Yanıtları

\begin{tabular}{|c|c|c|}
\hline Öğretmenler & Çünkü... & Örnek Yanitlar \\
\hline Ö2, Ö3, Ö8 & Aksi bir örnek yoktur & $\begin{array}{l}\text { Ö8: Rasyoneldir diye düşünüyorum. Aksi bir } \\
\text { örneğiyle hiç karşılaşmadım. Olacağını da } \\
\text { sanmıyorum. } 0 \text { ile de çarpsak sonuç } 0 \text { olur... } 0 \text { da } \\
\text { bir rasyonel sayıdır. }\end{array}$ \\
\hline $\begin{array}{l}\text { Ö4, Ö5, Ö6, } \\
\text { Ö7 }\end{array}$ & Sonuç hep $\frac{a}{b}$ şeklindedir & $\begin{array}{l}\text { Ö4: İki rasyonel sayı çarpılırken paylar ve } \\
\text { paydalar çarpıllyor ve yine } \frac{a}{b} \text { şeklinde bir rasyonel } \\
\text { sayı çkıyor. }\end{array}$ \\
\hline Ö1 & $\begin{array}{l}\text { Rasyonel sayılar } \\
\text { kapalıdır }\end{array}$ & $\begin{array}{l}\text { Ö1: Şimdi rasyonel sayıların pay ve paydası birer } \\
\text { tam sayı olduğundan bunların çarpımları ve } \\
\text { toplamları yine bir tamsayı olur. Yani } \frac{a}{b} \cdot \frac{c}{d}=\frac{a . c}{b . d} \\
\text { olur. Dolayısıyla kapalılık sağlanır ve sonuç } \\
\text { rasyonel olur. }\end{array}$ \\
\hline
\end{tabular}

Ö3: Evet iki rasyonel sayının çarpım sonucu da yine rasyonel bir sayıdır. Aksi bir örnek gösteremeyiz.

Ö5: İki rasyonel sayının çarpımı her zaman rasyoneldir. Aksi bir örnek yoktur zaten... Çünkü çarpma yapılırken pay ile pay payda ile de payda çarpılır. Sonuç olarak da yine $\frac{a}{b}$ şeklinde $a, b$ aralarında asal olan bir rasyonel sayı elde edilir.

\section{Sonuç, Tartışma ve Öneriler}

Matematik öğretmenlerinin mülakatlara verdikleri yanıtlarla ilgili araştırmada elde edilen sonuçlar bu bölümde tartışılmıştır. Araştırmada elde edilen bulgulara göre matematik öğretmenlerinin hem rasyonel hem de irrasyonel sayıların tanımlarını doğru bir şekilde yapamadıkları görülmüştür. Öğretmenlerin rasyonel sayıları tanımlamalarında rasyonel sayıların gösterimine odaklandıkları ve bu şekildeki ifadelerini yeterli gördükleri tespit edilmiştir. Formel (Matematiksel) tanım yapabilen öğretmenler ise rasyonel sayıların gösterimlerinin yanında pay ve payda da yer alan elemanların özelliklerini de net bir şekilde ifade etmişlerdir. Rasyonel sayıların tanımı ile ilgili yapılan eksiklikler irrasyonel sayıların da tam olarak tanımlanamamasına sebep olmuştur. Çünkü öğretmenler irrasyonel sayılar için sıklıkla "Rasyonel olmayan sayılardır" şeklinde tanımlar yapmışlardır. Dolayısıyla rasyonel sayılar tam olarak doğru bir şekilde tanımlanamadığı için irrasyonel sayılar için yapılan bu tanımlar eksik görülmüştür. İrrasyonel sayıların tanımı yapılırken öğretmenlerin irrasyonel sayıların ondalık gösterimleri üzerinde durmadıkları ya da eksik bilgiler verdikleri de araştırmada elde edilen önemli sonuçlar arasındadır. Öğretmenlerin irrasyonel sayıların ondalık gösterimleri ile ilgili tanımlarında verdikleri bilgilerin "virgülden sonrası sonsuza kadar devam eden sayılardır" şeklinde yanlış öğrenmelere sebep olacak nitelikte olduğu görülmüştür. Dolayısıyla öğretmenlerin ondalık sayıların irrasyonel olması için virgülden 
sonrasının tekrarsız ve sonsuz olması gerektiğini belirtmedikleri sonucuna ulaşılmıştır. Araştırmada elde edilen bu sonuçlar matematik öğretmenleri/öğretmen adayları ile yapılan ve rasyonel ve irrasyonel sayıların tanımlarının doğru bir şekilde yapılamadığını tespit eden çalışmaların sonuçlarını desteklemektedir (Arcavi, Bruckheimer ve Ben-Zvi, 1987; Fischbein, Jehiam ve Cohen, 1995; Güven, Çekmez ve Karataş, 2011).

Matematik öğretmenlerinin verilen bir sayı kümesindeki sayıları rasyonel ya da irrasyonel olarak tanımalarına yönelik yanıtları incelendiğinde $\frac{22}{7}, \frac{3}{\pi}, \sqrt{36}, 3+\sqrt{2}, 1,92713 \ldots$ şeklindeki rasyonel ve irrasyonel sayıların yanılgıya sebep olduğu görülmüştür. Öğretmenlerin bu sayılarla ilgili yaşadıkları sorunların temelinde rasyonel ve irrasyonel sayılara yönelik yaptıkları tanımların ve $\pi$ sayısının farklı gösterimlerinin olduğu söylenebilir. Özellikle öğretmenlerin sınıf içi uygulamalarındaki problem çözümlerinde $\pi=$ $\frac{22}{7}$ şeklindeki kabulleri hem kendileri hem de öğrencileri için $\frac{22}{7}$ rasyonel sayısının irrasyonel olarak algılanmasına sebep olabilmektedir. Benzer durumlar literatürde yer alan çalışmaların sonuçlarında da yer almaktadır (Fischbein, Jehiam ve Cohen, 1995; Güven, Çekmez ve Karataş, 2011). Güven, Çekmez ve Karataş (2011) öğrencilerin sayıların gösterimleri hakkındaki düşüncelerinin sayıların doğası hakkındaki kararlarını etkilediğini belirtmektedirler. Benzer durumların öğretmenler için de geçerli olduğu söylenebilir. Çünkü Ö6 $\pi$ sayısının irrasyonel olduğunu bilmesine rağmen rasyonel sayıların gösterimine fazlaca odaklanmasından dolayı $\frac{3}{\pi}$ nin rasyonel olduğunu ifade etmiştir. Benzer şekilde irrasyonel sayıların ondalık gösterimleriyle ilgili bilgi eksikliğinden kaynaklı olarak 1,92713 ... sayısının rasyonel olduğu şeklinde yanıt veren bir öğretmenin olduğu görülmüştür. Bununla birlikte öğretmenlerin köklü ifadelerle irrasyonel sayıları birlikte düşündükleri tespit edilmiştir. Bu durum bazı öğretmenlerin $\sqrt{36}$ sayısının irrasyonel ya da rasyonel olması noktasında tereddütler yaşamalarına sebep olmuştur. Benzer sonuçlara ilköğretim öğrencileri (Temel ve Eroğlu, 2014), lise öğrencileri (Kara ve Delice, 2012) ve öğretmen adaylarıyla (Güven, Çekmez ve Karataş, 2011) yapılan çalışmalarda da ulaşılmıştır. Bu yüzden öğretmenlerin hem kendileri hem de öğrencileri açısından kavramların öğretiminde her seviyedeki öğretimlerinde titizlikle davranmaları gerekmektedir. Çünkü literatürde yer alan araştırmalarda da farklı örneklem gruplarında yer alan katılımcıların benzer hataları yaptıkları görülmektedir. Ayrıca Güven, Çekmez ve Karataş (2011) özellikle lise matematik derslerinde irrasyonel sayıların farklı gösterimlerine yönelik örneklerin çeşitlendirilmesinin öğrencilerin irrasyonel sayıları daha iyi tanımalarına olanak sağlayacağını belirtmektedirler. Dolayısıyla matematik öğretmenlerinin irrasyonel sayılarla ilgili örneklerini çeşitlendirmelerinin kendi kavram gelişimlerini de olumlu yönde etkileyeceği düşünülmektedir.

Matematik öğretmeni adaylarıyla irrasyonel sayıların sayı doğrusu üzerindeki tam yerini belirlemeye yönelik araştırmalarda adayların irrasyonel sayıların sayı doğrusu üzerindeki yerlerini bulmakta güçlükler yaşadıkları ve sezgisel çıkarımlar yaptıkları sonuçlarına ulaşılmıştır (Peled ve Hershkovitz, 1999; Sirotic, 2004; Sirotic ve Zazkis, 2007). Benzer şekilde öğretmenlerin de $\sqrt{2}$ sayısının sayı doğrusu üzerindeki tam yerini belirlemekte güçlük yaşadıkları tespit edilmiştir. Literatürde yer alan çalışmalarda olduğu gibi öğretmenlerin 
irrasyonel sayıları geometrik olarak uzunluk kavramıyla ilişkilendiremediği ve daha çok sezgisel yanıtlar verdikleri görülmüştür. Sirotic ve Zazkis (2007) irrasyonel sayıların kendi içerisinde oldukça zor bir kavram olduğunu ancak okullarda uygulanan programlarda reel sayı eksenindeki her noktanın bir reel sayı karşılığının var olduğunun vurgulandığını belirtmektedirler. Benzer şekilde ülkemizde de ortaokul 8. sınıf ve lise 9. sınıf ders kitaplarında irrasyonel sayıların sayı doğrusu üzerindeki yerlerinin bulunmasına yönelik etkinlikler yer almasına rağmen öğretmenlerin irrasyonel sayıların sayı doğrusu üzerindeki yerlerinin bulunamayacağı ya da tahmini olarak bulunabileceği şeklinde yanıtlar vermeleri düşündürücüdür. Bu güçlüklerin aşılması için Geometrik Yaklaşımların (Pisagor Teoreminin kullanımıyla $\sqrt{2}$ nin tam yerinin belirlenmesi) irrasyonel sayıların öğretiminde kullanılması literatürde yapılan benzer çalışmalarda (Güven, Çekmez ve Karataş, 2011; Peled ve Hershkovitz, 1999; Sirotic, 2004; Sirotic ve Zazkis, 2007) önerildiği görülmektedir.

Matematik öğretmenlerinin iki irrasyonel ya da iki rasyonel sayı arasına başka sayılar yazmalarına yönelik bulgular incelendiğinde yanıtların farklı stratejiler kullanılarak verildiği görülmüştür. Öğretmenler özellikle iki irrasyonel sayı arasına başka bir irrasyonel sayı yazmakta güçlük yaşamışlardır. İki irrasyonel sayı arasına başka bir irrasyonel sayı yazılırken kullanılan stratejiler içerisinden sadece Ondalık Sayı Yaklaşımına göre yanıt veren öğretmenlerin istenilen aralıkta irrasyonel sayılar yazabildikleri belirlenmiştir. Diğer stratejilerin kullanıldığı yanıtlarda öğretmenlerin yazdıkları irrasyonel sayıların yaklaşık değerlerini belirleyemedikleri ve hatalı olduğu gözlenmiştir. Bununla birlikte öğretmenlerin iki rasyonel sayı arasına bir irrasyonel sayı yazarken nispeten daha rahat oldukları tespit edilmiştir. İki rasyonel sayı arasına bir irrasyonel sayı yazmak için kullanılan Kök Alma ve Ondalık Sayı Yaklaşımlarını kullanan öğretmenlerin istenilen aralıkta bir irrasyonel sayı yazdıkları görülmüştür. Ancak Sezgisel Gösterim yapan öğretmenlerin yanıtlarının diğer stratejilere göre daha çok tahmine dayandığı ve istenilen aralıkta olmadığı belirlenmiştir. Benzer şekilde öğretmenlerin iki irrasyonel sayı arasına bir rasyonel sayı yazmak için kullandıkları stratejilerden; Yaklaşık Değer ve Kare Alma Yaklaşımlarının kullanıldığı yanıtların istenilen aralıkta rasyonel sayılar olduğu görülmüştür. Ancak Sezgisel Gösterim kullanılan yanıtların diğer stratejilerin kullanıldığı yanıtlara göre daha sı̆̆ kaldığı tespit edilmiştir. Ancak öğretmenlerin iki rasyonel sayı arasına başka bir rasyonel sayı yazarken çok daha rahat oldukları gözlenmiştir. Öğretmenler bu tip problemleri sınıf ortamında da kullandıklarını ifade etmişlerdir. Dolayısıyla özellikle 9. sınıf matematik ders kitaplarında irrasyonel sayılarla ilgili iki irrasyonel sayı arasına irrasyonel ya da rasyonel sayı ve iki rasyonel sayı arasına bir irrasyonel sayı yazma etkinlikleri yer almasına rağmen öğretmenlerin bunlara çok fazla değinmedikleri söylenebilir. Sirotic ve Zazkis (2007) matematik öğretmeni adaylarının irrasyonel sayılarla ilgili işlemlerde özellikle ondalıklı gösterimleri üzerine odaklanıldığını ve bu durumun irrasyonel sayıların kavramsal olarak öğrenilmesine katkı sağlamadığını belirtmişlerdir. Araştırmada elde edilen sonuçlar öğretmenler açısından da irrasyonel sayılarla ilgili bu tarz problemlerde ondalıklı gösterimlerin ve yaklaşık değer hesaplarının sıklıkla kullanıldığını desteklemektedir. Benzer şekilde Güven, Çekmez ve Karataş (2011) sayı doğrusu üzerine sayıların yerleştirilmesinde öğretmen adaylarının doğru yanıt oranlarının yüksek olmasına rağmen yanıtların 
gerekçelerinin gösteriminde formal ifadelere göre sezgisel ifadelerin daha fazla kullanıldığı sonucuna ulaşmışlardır.

Matematik öğretmeni adaylarının irrasyonel sayılar kümesi üzerinde yapılan işlemlerin kapalılığı ile ilgili düşüncelerini inceleyen araştırmada Güler, Kar ve Işık (2012) öğretmen adaylarının irrasyonel sayıların çarpma işlemine göre neden kapalı olmadığını açıklamakta güçlük yaşadıkları sonucuna ulaşmışlardır. Ayrıca bu işlemin nasıl yapıldığına yönelik öğretmen adaylarının açıklamalarının sınırlı olduğunu ifade etmişlerdir. Çalışmada matematik öğretmenlerinin de benzer güçlükler yaşadıkları görülmüştür. Matematik öğretmenlerinin iki irrasyonel sayının toplamının sonucuna yönelik 5 (Ö2, Ö3, Ö4, Ö5, Ö6) öğretmenin "her zaman irrasyoneldir" şeklinde düşündükleri görülmüştür. Bu şekilde düşünen öğretmenler iki irrasyonel sayının toplamının kapalı olmadığını gösteren aksi bir örneğin bulunamayacağını ifade etmişlerdir. Araştırmada elde edilen bu sonuç matematik öğretmenlerinin irrasyonel sayıların toplama işlemine göre kapalı olduğunu düşünebileceklerini göstermektedir ki bu durum eğitim verdikleri öğrencilerin irrasyonel sayılarla yapılan işlemleri anlama ve içselleştirmeleri için büyük bir engel teşkil edebilir. Çünkü 9. sınıf lise matematik ders kitaplarında benzer etkinlikler olduğu için bu öğretmenlerin kendi kavram yanılgılarını öğrencilerine de aktarabilecekleri söylenebilir. Bununla birlikte iki irrasyonel sayının toplamına "her zaman irrasyonel değildir" şeklinde yanıt veren öğretmenlerin ise kapalı olmayan bir işlemin irrasyonel sayılar kümesinde nasıl yapıldığını bilmediklerini ya da kabul olabileceğini ifade ettikleri görülmüştür. Bu yüzden araştırmada elde edilen bu sonuç öğretmenlerin kendi durumlarını görebilmeleri açısından oldukça önemlidir.

Çalışmaya katılan matematik öğretmenleri iki irrasyonel sayının çarpımının sonucunun her zaman irrasyonel olmayacağını ifade etmişlerdir. Dolayısıyla öğretmenlerin irrasyonel sayıların çarpma işlemine göre kapalı olmadığının toplama işlemine göre daha fazla farkında oldukları görülmüştür. Öğretmenlerin özellikle köklü ifadelerde çarpma işlemi yaparken sıklıkla benzer durumlarla karşılaşmalarının bu durumda etkili olduğu söylenebilir. Ancak öğretmenlerin irrasyonel sayılar kümesinde kapalı olmayan çarpma işlemini bu küme üzerinde nasıl yaptıklarını açıklamakta güçlük yaşadıkları görülmüştür. Sadece 2 (Ö2, Ö3) öğretmenin çarpma işleminin kapalı olduğu reel sayılar kümesi üzerinde tanımlandığı için bu işlemi yapabildiklerini ifade edebilmiştir. Diğer öğretmenlerin ise bilmiyorum, kabuldür ve üslü/köklü sayılar olarak düşündügümüz için yapılabilir şeklinde yanıtlar verdikleri tespit edilmiştir. Dolayısıyla öğretmenlerin irrasyonel sayılar kümesi üzerinde yapılan işlemlere yönelik kavramsal eksikliklerinin olduğu sonucuna ulaşılmıştır. Bununla birlikte matematik öğretmenlerinin iki rasyonel sayının toplamı ve çarpımının sonucunun her zaman rasyonel olacağının farkında oldukları görülmüştür. Öğretmenler tarafından irrasyonel sayıların aksine rasyonel sayılarla yapılan işlemlerin kapalı olduğunun farkında oldukları belirlenmiştir. $\mathrm{Bu}$ durumun öğretmenlerin sıklıkla bu küme üzerinde çalışmalarından ve sınıf içi uygulamalarında rasyonel sayılarla yapılan işlemler üzerine daha fazla odaklanmalarından kaynaklandığg söylenebilir. 
$\mathrm{Bu}$ araştırma 8 matematik öğretmeni ile yapılan yarı yapılandırılmış mülakatlar ile sınırlıdır. Araştırmada matematik öğretmenlerinin irrasyonel sayılarla ilgili genel olarak formel matematiksel bilgiler kullanmak yerine daha çok sezgisel yanıtlar verdikleri sonucuna ulaşılmıştır. Dolayısıyla bu araştırmada elde edilen öğretmenlerin irrasyonel sayılarla ilgili tanımlama, tanıma, sayı doğrusu üzerinde irrasyonel sayıların tam yerinin göstermesi ve irrasyonel sayılar kümesi üzerinde yaptıkları işlemlere yönelik yaşadıkları güçlükler dikkate alınarak daha geniş katılımlı araştırmaların yapılması önerilebilir. Çünkü öğretmenlerin irrasyonel sayılarla ilgili sıralanan durumlarda yaşadıkları güçlükler ve yanılgılar öğretim yapacakları öğrencilere de aktarabilecekleri düşünülmektedir. Aynı zamanda öğretmenlerin irrasyonel sayılarla ilgili etkili ders içeriğini ve etkinliklerini hazırlamasında ders kitaplarının önemine araştırmada dikkat çekilmektedir. $\mathrm{Bu}$ yüzden araştırma sonuçlarının matematik öğretmenlerinin ve dolaylı olarak da öğrencilerin irrasyonel sayılarla ilgili kavramsal gelişimlerinin sağlanmasında kullanılabileceği düşünülmektedir. 


\section{Kaynakça}

Adıüzel, N. (2013). Illköğretim matematik öğretmen adayları ve 8. sinıf öğrencilerinin irrasyonel saylar ile ilgili bilgileri ve bu konudaki kavram yanılgılar. (Yayımlanmamış yüksek lisans tezi). Necmettin Erbakan Üniversitesi, Eğitim Bilimleri Enstitüsü, Konya.

Arcavi, A., Bruckheimer, M., ve Ben-Zvi, R. (1987). History of mathematics for teacher: The case of irrational numbers. For the Learning of Mathematics, 7(2), 18-23.

Baki, A. (2008). Kuramdan uygulamaya matematik ě̆itimi. Ankara: Alfa Yayınları.

Büyüköztürk, Ş., Kılıç-Çakmak, E., Akgün, Ö. E., Karadeniz, Ş., ve Demirel, F. (2011). Bilimsel araştırma yöntemleri. Ankara: Pegem Akademi.

Ercire, Y. E. (2014). İrasyonel sayı kavramına ilişkin yaşanılan güçlüklerin incelenmesi. (Yayımlanmamış yüksek lisans tezi). Dokuz Eylül Üniversitesi Eğitim Bilimleri Enstitüsü, İzmir.

Ercire, Y. E., Narlı, S. ve Aksoy, E. (2016). İrrasyonel sayı kümesinin rasyonel ve gerçek sayı kümeleriyle olan ilişkisine yönelik öğrenme güçlükleri. Türk Bilgisayar ve Matematik Ĕ̆itimi Dergisi, 7(2), 417-439.

Fischbein, E., Jehiam, R., ve Cohen, D. (1995). The concept of irrational numbers in high school students and prospective teachers. Educational Studies in Mathematics, 29(1), $29-44$.

Güler, G., Kar, T., ve Işı1k, C. (Haziran, 2012). Matematik öğretmeni adaylarının irrasyonel ve reel sayılar arasındaki ilişkiyi belirleyebilmeleri üzerine nitel bir çalışma. X. Ulusal Fen Bilimleri ve Matematik Eğitimi Kongresi'nde sunulmuş bildiri. Niğde Üniversitesi, Niğde, Türkiye.

Güven, B., Çekmez, E., ve Karataş, İ. (2011). Examining preservice elementary mathematics teachers' understanding about irrational numbers. Problems, Resources, and Issues in Mathematics Undergraduate Studies (PRIMUS), 21(5), 401-416. DOI: 10.1080/10511970903256928

Kara, F., ve Delice, A. (Haziran, 2012). Kavram tanımı mı? Yoksa kavram imgeleri mi? Irrasyonel saylların temsilleri. X. Ulusal Fen Bilimleri ve Matematik Eğitimi Kongresi'nde sunulmuş bildiri. Niğde Üniversitesi, Niğde, Türkiye.

Milli Eğitim Bakanlığı (MEB), (2013a). Ortaokul (5-8). sinıflar öğretim programı. Milli Ĕ̆itim Bakanlı̆̆ Talim ve Terbiye Kurulu Başkanlı̆̆ı. Ankara: Devlet Kitapları Müdürlüğü Basım Evi.

Milli Eğitim Bakanlığı (MEB), (2013b). Ortaöğretim (9-12). sinıflar programları tanıtım el kitabı. Milli Ĕgitim Bakanlı̆̆ Talim ve Terbiye Kurulu Başkanlı̆̆ı. Ankara: Devlet Kitapları Müdürlüğü Basım Evi. 
Milli Eğitim Bakanlığı (MEB), (2015a). 8. Sinıflar matematik ders kitabı. Milli Eğitim Bakanlı̆̆ Talim ve Terbiye Kurulu Başkanlığı. Ankara: Devlet Kitapları Müdürlüğü Basim Evi.

Milli Eğitim Bakanlığı (MEB), (2015b). 9. sınıflar matematik ders kitabı. Milli Eğitim Bakanlı̆̆ Talim ve Terbiye Kurulu Başkanlığı. Ankara: Devlet Kitapları Müdürlüğü Basım Evi.

National Council of Teachers of Mathematics [NCTM], (2000). Principles and standarts for school mathematics. Reston, VA: National Council of Teachers of Mathematics.

Peled, I., ve Hershkovitz, S. (1999). Difficulties in knowledge integration: Revisiting Zeno's paradox with irrational numbers. International Journal of Mathematics Education, Science and Technology, 30(1), 39-46.

Sirotic, N., ve Zazkis, R. (2007). Irrational numbers on the number line-Where are they?. International Journal of Mathematics Education, Science and Technology, 38(4), 477488.

Srotic, N. (2004). Prospective secondary mathematics teachers' understanding of irrationality (Yayımlanmamış yüksek lisan tezi). Simon Fraser University, British Colombia, Canada.

Temel, H., ve Eroğlu, A. O. (2014). İlköğretim 8. Sınıf öğrencilerinin sayı kavramlarını anlamlandırmaları üzerine bir çalışma. Kastamonu Eğitim Fakültesi Dergisi, 22(3), 1263-1278.

Zazkis, R. (2005). Representing numbers: Prime and irrational. International Journal of Mathematics Education, Science and Technology, 36(2-3), 207-218. 